Portland State University

PDXScholar

Dissertations and Theses

Dissertations and Theses

Spring 6-14-2019

\title{
Politics in the San Clemente Dam Removal
}

Aylan Matthew Lee

Portland State University

Follow this and additional works at: https://pdxscholar.library.pdx.edu/open_access_etds

Part of the Geography Commons

Let us know how access to this document benefits you.

\section{Recommended Citation}

Lee, Aylan Matthew, "Politics in the San Clemente Dam Removal" (2019). Dissertations and Theses. Paper 5032.

https://doi.org/10.15760/etd.6908

This Thesis is brought to you for free and open access. It has been accepted for inclusion in Dissertations and Theses by an authorized administrator of PDXScholar. Please contact us if we can make this document more accessible: pdxscholar@pdx.edu. 
Politics in the San Clemente Dam Removal

by

Aylan Matthew Lee

A thesis submitted in partial fulfillment of the requirements for the degree of

Master of Science

in

Geography

Thesis Committee:

Barbara Brower, Chair

Britt Crow-Miller

Hunter Shobe

Alida Cantor

Portland State University

2019 


\begin{abstract}
$\underline{\text { Abstract }}$
This study examines the role of politics in the removal of the 106-foot tall San Clemente Dam. The removal project and negotiations provide a case study of the contemporary phenomenon of dam removal. My analysis joins a growing body of social science literature on the social, political, and human dimensions of removal. The San Clemente Dam, which impounded the Carmel River near Monterey, California, was removed in 2015, the largest such project completed in California. Drawing on political ecology and science and technology studies, and using a mixed qualitative approach, I assess both the role of politics in shaping the project and the politics affected through or by the removal. I use a broad, historically attentive analysis of the region to contextualize the political elements of the project. My findings demonstrate and focus on several political dimensions of the removal project, including funding, micro-political strategies, and the prioritizing of particular ecosystem functions and services in the post-removal landscape.
\end{abstract}




\section{Dedication}

This thesis is dedicated to Sabine Lang, Lucy Jarosz, Katharyne Mitchell, Britt CrowMiller, and Barbara Brower, scholars and luminaries who each have shepherded me along my academic and intellectual journey and shown me the true delight in this sort of work.

To have briefly walked among them has been one of the pleasures of my life. 


\section{$\underline{\text { Acknowledgements }}$}

From beginning to end, this thesis has benefited from the involvement of scholars, friends, and family. Whatever success I found this process is surely owed to the many individuals who have touched this project. At Portland State University, Lindsay Skog, Heejun Chang, and Martin Lafrenz (among many others) all deserve credit for volunteering their time and attentions to my studies and ideas. My experiences were similarly enriched by the camaraderie of many graduate students in the PSU Geography Department.

I also owe thanks to the many individuals beyond the university who took the time to speak with me about the San Clemente Dam. This research was made possible by the insights of many around the Monterey Peninsula. Farther afield, my serendipitous river trips with Anne MacDonald and Larry Hampson shaped this study and my graduate career.

This thesis very nearly became a forever-unfinished project and I am indebted to the continued faith and effort of my committee members. During my years at Portland State, Hunter Shobe became a trusted role model and valued source of insight. Alida Cantor provided me with early opportunities to share my ideas about dam removal. Her willingness to join my committee late in the game and ability to contribute pertinent, insightful feedback were key factors in my ability to finish.

I was furthermore blessed to receive guidance from a heroic duo of advisors. Britt Crow-Miller has been a patient source of insight and overwhelming support. Her willingness to let me explore these topics (at my own pace, even) did not go unnoticed and the diligence she shows in this and all her work remains an inspiration. Barbara 
Brower provided perspective, wisdom, and constant intellectual challenge. My graduate experience was thoroughly enlivened by her presence and advisement. How lucky I was to have worked with each and both of them.

My family supported this work in ways I am only now coming to grasp. For their continued enthusiasm, patience, and understanding through this and all my endeavors, I extend heartfelt thanks both to Mary Neuer Lee and George Lee. And to Keenan Lee, who provided the same, and unknowingly taught me how to accomplish daunting tasks. I also want to extend a similar appreciation to the many friends and colleagues who offered safe harbor or chose to listen during the last few years. Special thanks goes to Shawn Crawford and Peter Metcalf, kind friends and wise counsellors. Kate Hohenstein also deserves recognition. For her generous editing and unremitting encouragement I am profoundly grateful. 


\section{$\underline{\text { Table of Contents }}$}

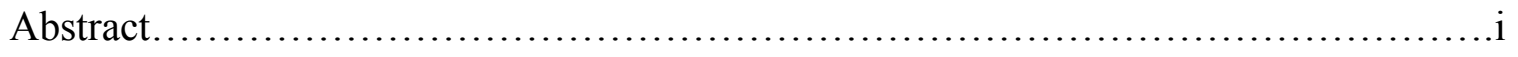

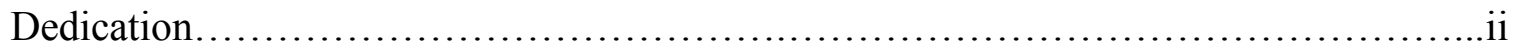

Acknowledgments..........................................................

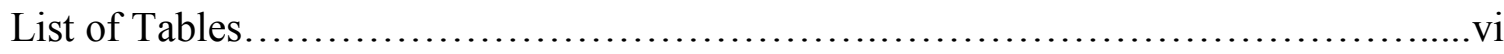

List of Figures............................................................

List of Abbreviations......................................................... viii

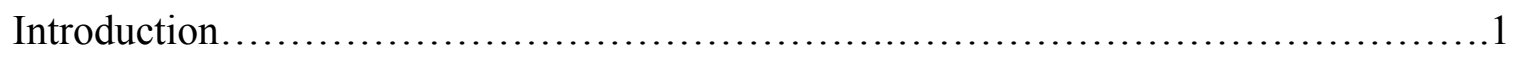

Literature Review and Key Theoretical Arguments................................8

Methods.................................................................21

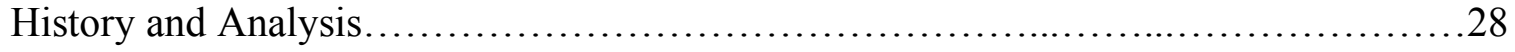

Conclusion, Discussion, and Future Directions................................63

References.............................................................. 71

Appendix: Semi-Structured Interview Questions.................................. 78 


\section{$\underline{\text { List of Tables }}$}

Table 1. Interview Subjects.

Table 2. San Clemente Dam Timeline.

Table 3. Project Costs and Funding. 


\section{List of Figures}

Figure 1. Adapted map of the region and project area.

Figure 2. Photograph of the San Clemente Dam prior to removal.

Figure 3. Adapted reroute project map.

Figure 4. Aerial photo of project site showing reservoir and sediment accumulation.

Figure 5. Photograph of the post-removal landscape.

Figure 6. Development in the lower Carmel River valley. 


\section{List of Abbreviations}

BLM - Bureau of Land Management

Cal Am - California American Water

CDWR - California Department of Water Resources

CPUC - California Public Utilities Commission

CRSA - Carmel River Steelhead Association

DOSD - Division of Safety of Dams

DRA - Division of Ratepayer Advocates

EIR - Environmental Impact Report

EIS - Environmental Impact Statement

ESA - Endangered Species Act

MCE - Maximum Credible Earthquake

MPWMD - Monterey Peninsula Water Management District

NMFS - National Marine Fisheries Service

PMF - Probably Maximum Flood

RDEIR - Recirculated Draft Environmental Impact Report

SCC - State Coastal Conservancy

STS - Science and Technology Studies

USACE - United States Army Corps of Engineers

WCC - Woodward-Clyde Consultants 


\section{Introduction}

Once an impressive centerpiece to regional development and a proud achievement of pre-depression civil engineering, the San Clemente Dam reached the end of its structural lifespan as a used-up impediment. Located on the Carmel River near California's Central Coast, the dam formerly impounded 1500 acre-feet of water and helped supply water to the Monterey Peninsula. When the dam was finally removed in 2015, the reservoir contained only a minute fraction of its former volume. Behind the dam's 106-foot concrete arch rested some 2.5 million cubic yards of accumulated sediment, a problem at the center of a long-running compendium of social, political, and ecological issues. When it finally came down, the San Clemente was the largest dam ever removed in the state of California and among the most expensive of such projects in the nation.

The San Clemente dam removal (officially, the Carmel River Reroute and San Clemente Dam Removal) was unique not only in size and cost, but was also notable for the novel approach and design it employed. Given the massive sediment load behind the dam, and the consequences of removing or releasing that sediment downriver, the stakeholders and decision-makers chose instead to leave the sediment in place, sequestering it in the former riverbed. To do so, the Carmel River was rerouted 450 feet through an intervening ridge and into the bed of nearby San Clemente Creek. Accomplishing this diversion required extensive engineering and channel design, but allowed the sediment to remain in place, even after the tall dam was removed.

The events that precipitated the removal efforts of the San Clemente, and the landscape that resulted from that novel feat of engineering, are at the heart of this study. 
Specifically, and with attention to multiple factors, I explore the role and work of politics, both in the removal process and in the landscape it yielded. While the decades-long project to bring down the dam ostensibly considered what to do with a riverine ecosystem, the process and decision-making played out across a social and political landscape.

Dams sit at the nexus of environment and technology. As material objects, they transform something categorically natural (a river) into something transferable, useable (drinking water in this case) and technological. The human purposes and ends for which dams are built give light to their position as inherently political object; in their massive and seemingly immovable state, they project those inherent politics or values into the future. Indeed, the sheer mass of large dams ensures some lasting impacts on communities around them.

Because of these impacts, when dams (like the San Clemente) reach the inevitable end of their service life, the proportions of the questions at hand ensure an outsized significance. Like all artifacts of infrastructure, dams, and the systems they comprise, eventually decay, prompting, at the very least, the question "what should be done?", not to mention issues of "by whom", and "how." Answering or addressing these questions is itself a political, value-laden, and socially shaped process. Bureaucrats, engineers, and a sometimes-bewildering array of stakeholders and actors are asked or compelled to assist the re-appraisal of infrastructure and the creation of a new (if "restored") landscape.

From this process emerges the post-removal landscape, which in the case of the San Clemente comprised a rerouted stretch of river and dramatic engineering of the surrounding ecosystem. While this production (the remaking of the physical landscape) is 
less obviously the result of highly technical engineering, the post-removal landscape may often be the outcome of a far more involved decision-making process than the construction of the dam that preceded it. In this way, the artifact of a dam removal is akin to a dam itself in its ability to assist, enact, or project the values of its designers.

The ideas presented above comprise the heart of this study: that dams project politics, that removals are socially and politically shaped, and that the post-removal landscape also projects the politics inherent in its design. I investigate and explain the role of politics in the removal of the San Clemente Dam, addressing my primary research question: how do politics figure into dam removal? Subsequently, I investigate the following secondary questions:

1. How are politics embedded in the post-removal landscape?

2. How are politics represented in the discourses surrounding the removal of the San Clemente Dam?

3. How did these political discourses shape or enable the dam removal project?

In examining dam removal and how it may be shaped by or imbued with politics, I acknowledge that politics alone is unlikely to account for the outcome of a removal project. Rather, politics is one amongst a host of drivers. In exploring this key variable (politics), I consider the full spectrum of agencies, forces, and factors at work in the removal process. In theoretical terms, this manifests as an attention to what Sarah Pritchard (2011) has called the enviro-technical system; "historically and culturally specific configurations of intertwined 'ecological' and 'technological' systems, which may be composed of artifacts, practices, people, institutions, and ecologies" (19). In more 
general terms, I draw primarily on scholarship within political ecology and science and technology studies (STS). Each academic body brings clarifying advantages - political ecology with its attention to the interaction of environmental change and politics, STS in its social constitution of artifacts of technology. The intersection of both frameworks proves to be a fruitful space of inquiry, a theoretical wellspring.

I begin this study by establishing the theoretical lens that directs my investigation, and continue with a literature review outlining several key fields that have informed my findings. I provide an overview of the relevant bodies of work within STS and political ecology, and pertinent multidisciplinary works that address the subject of dams, infrastructure, and environmental restoration, particularly within the realm of social science.

Within my theory-focused discussion of STS, I outline both the general utility of STS as an analytic framework, as well as several specific concepts that inform my research and analysis. Broadly, STS informs this study through its attention to the embroilment of technologies within social networks and systems and the material significance of artifacts of technology such as dams. The field has seen a recent turn towards infrastructure (see, for instance, Crow-Miller et al. 2017). I also draw several key concepts from scholars aligned with STS, specifically citing literature on obduracy, techno-politics, and the enviro-technical system, which serve to clarify and explicate the results of my research.

Similarly to STS, political ecology offers a context for this study, and contributes key concepts. This study aligns with political ecology in its attention to the political origins of environmental change. Moreover, within this thesis I emulate classic works of 
political ecology (see Hecht 1985, for instance), opting for an ideographic study and focusing on contingency and complexity with respect to the San Clemente Dam removal, rather than searching for commonalities with other removals. I attempt to produce a thoroughly "regional political ecology," answering a call for work which focuses on the situated uniqueness and intricacies of place (Walker 2003).

To summarize my literature review, I outline a theoretical framework appropriate for analyzing the ways in which politics figure into (a specific) dam removal. Namely, that by assessing the enviro-technical regime within which a dam, its removal efforts, and the post-removal landscapes are situated, we might gain insight both into the work of those political forces to shape and allow removal, and also into the political efficacy of the landscape or artifacts that remains when the dam is gone.

Subsequent to the literature review, I provide a general overview of the methods involved in this study. The data for this analysis was generated through seven qualitative, semi-structured interviews completed between 2016 and 2017. The interview data is complimented by a body of archival research. Although the original design of this study focused heavily on performing discourse analysis with transcribed interviews, the final analysis rests on a detailed understanding of the historical conditions and regimes which led towards removal. Nevertheless, the ten-plus hours of interview recordings were transcribed and analyzed for the presence of political or politicized discourses.

My analysis plays out across three subsections, each oriented toward a different topic and presenting a roughly chronological account of the San Clemente Dam and its removal. This system of organization allows for the presentation of a detailed history of the enviro-technical system, the dam itself, its removal, and the removal's aftermath. 
The first analytic subsection ("Outlining the System") provides historic and geographic context for the 2015 removal project. In describing the enviro-technical system within which the San Clemente dam was situated, I focus on the mutually intertwined histories of water and development on the Monterey Peninsula throughout the twentieth century. Understanding of the broader, statewide water-history provides context and explanatory potential, both historically and in my analysis, to the system and regime that emerged with respect to the San Clemente dam. I also include in this section a brief analysis of the intertwined, co-mingled, and co-produced elements and phenomena that directly contributed to the obduracy of the dam during and after its service life.

In the second subsection ("Lead-up to Removal"), my analysis shifts towards the conditions and motivations that led to inertia for the removal project. This subsection provides policy background and an overview of the constellation of actors involved in the removal, particularly the biogeophysical phenomenon (fire, sedimentation) that precipitated removal, critical regulatory and policy junctures (including seismic surveys and mandates by various state and federal agencies), and a dynamic suite of stakeholders (the dam owner, National Marine Fisheries Service, and local advocacy groups).

Having established the conditions precipitating the removal decision, the next subsection ("Funding") describes a number of critical junctures and events that illustrate the local enviro-technical system, pertinent political actions and outcomes, and challenges in the work of translating dam removal (described as a technology) to the Carmel river. This section describes the mechanics of funding the project and explores the issues surrounding that process, which constituted a critical juncture in its political implications and outcomes. I close by describing the coalescent design of the removal 
and reroute.

The final subsection looks directly at the post-removal landscape as a novel landscape and an artifact of technology. I argue that the landscape and its design demonstrate the work of certain value-laden processes, particularly concerning anadromous fish and sediment. Furthermore, I suggest that the form the removal took (that of reroute and sediment storage) is tied to the altered, but nevertheless recognizable and ongoing enviro-technical system of the region. The physical artifact of the dam removal within the regional enviro-technical system, the post removal landscape, shows evidence of the discourses of liability and risk that were identified in my qualitative interviews. These discourses shaped the removal process, illustrate the pre-existing enviro-technical regime, and demonstrate the work of politics through technology, wherein even the post-removal landscape contributes to the continued political order and status-quo of the Monterey Peninsula.

This study closes with a summary and integration of the concepts presented in the analysis. In particular, I stress the ways in which my theoretical framework draws attention to and helps to locate pertinent political issues with respect to the San Clemente dam removal and reroute. I also show that the vignettes and objects of analysis comprising the key subject matter of the removal offered in my study, while far from exhaustive, serve to demonstrate the ways in which politics shaped and were imbricated throughout the project. In closing, based on my findings I offer additional directions, both topical and theoretical, that future research might take on the matters of dam removal in general, and the San Clemente case in particular. 


\section{Literature Review and Key Theoretical Arguments}

\section{Overview}

This project is informed most significantly by the fields of political ecology and science and technology studies (STS). The critical nature of political ecology coupled with the attention to the politics of physical artifacts of technology inherent to technopolitics, a sub-field of STS, sets the stage for the rich conceptual framework within which I situate this research. My research also draws on literature beyond these fields, consulting general scholarship on rivers, water management, dams, and environmental restoration in order to gain a more thorough picture of the factors influencing dam removal.

\section{Political Ecology}

Since its inception in the 1980s, political ecology has developed considerable breadth in terms of scholars and subject matter. Paul Robbins (2004) offers several keen insights into the nature of political ecology, first arguing that political ecology is as much a way of doing research as it is a field of study, and further emphasizing that what defines this way of doing research is what it is not, namely "apolitical" ecology. An apolitical ecology takes for granted concepts such as nature, scarcity, and even politics (defined as a formal, legislated field), ignoring the influence of social factors, marginalization, and political economy on issues including landscape change, environmental degradation, and access to resources. Similarly, James McCarthy $(2002,1283)$ argues that it is the presence of a set of themes within individual case studies that "defines political ecology

more than any consistent theoretical or methodological approach to them." So, while the 
field is not marked by a predefined way of doing things, it is unified by a genealogy of themes and ideas that underlie its structure.

Geographically, the San Clemente Dam Removal project falls within the American West, specifically within a relatively affluent part of California. This is a somewhat atypical location for study in this field, as historically, the majority of political ecology fieldwork has focused on rural issues in developing countries. Nevertheless, several prominent political ecologists have argued for the place and role of a so-called First World political ecology. Walker (2003), Schroeder (2005), and McCarthy (2002) all point out that the tools, concepts, and methods of political ecology developed abroad could (and perhaps should) be translated into a first-world context. In his analysis of the Wise Use Movement, which occurred during the 1980s and 1990s in the American West, McCarthy illustrates how in focusing their studies on other parts of the world, academics overlooked the analogous struggles occurring locally.

Beyond political ecology (and in its disciplinary antecedent, cultural ecology), Bernard Nietschmann (2001) conveys a similar message through his conceptual "Beverly Hills Geographer." Nietschmann posits that the process of social science research and the relationship between researcher and "subject" commonly mirrors existing social dynamics and power differentials. Academic researchers, the critique implies, are disinclined to examine, or dissuaded from examining individuals or communities of a higher class or social standing. This insight inspires my own work and I hope to bring to bear a similarly critical lens on topics and geographies that have generally received less attention within the political ecology literature.

The Carmel River basin and surrounding communities clearly fit within the 
context of a first-world political ecology. Furthermore, the communities in proximity to the dam, as well as those served by the private water company that owned the dam, are generally affluent. The use of political ecology in this instance is therefore somewhat novel, as it has been applied more commonly in studies of marginality and development. This application is nevertheless fitting, as the fundamental concepts of political ecology do not suddenly cease to apply where privilege increases. By focusing on political ecology as a way of doing research, I hope to bring a critical perspective to bear on this novel case study and explicitly address the socioeconomic context of some of California's most expensive real estate.

In keeping with the genealogy of political ecology research, this study employs a broad, generally conventional definition of politics. Peter Walker provides a useful summary of politics as 'the panoply of 'processes and mechanisms' through which power is circulated and wielded“ $(2007,364)$. I examine politics as something that shaped the San Clemente dam removal and also as an outcome of the same process. Walker's definition is necessarily flexible enough to encompass the multitude of forms through which politics figure into dam removal. The limits of this definition and approach to politics (and subsequent opportunities for theoretical development) are discussed at the end of my conclusion chapter.

\section{Dams and Dam Removal}

Dams span the physical and conceptual space between nature and infrastructure. As integral objects in water management, they are embedded within complex systems, linking people, technology and natural elements. A wide range of recent scholars 
(Evenden 2009, Bijker 2007, Brooks 2009, Kaika 2006, White 2011) have examined how dams are a physical manifestation of politics built into the landscape, but the process of dam removal has, until recently, not received the same critical academic attention (see Grabowski et al. 2017 for some compelling recent work). Given a recent spate of highprofile dam removals across the United States (see Blumm and Erickson 2012, for example) and the likelihood that more will soon follow (McCully 1996), the removal of dams constitutes a propitious area of inquiry.

While critically oriented social science analyses of dam removal have begun to emerge only recently, biophysical and geophysical assessments of removals have proliferated (see, for instance, Doyle et al. 2003, Doyle et al. 2005, Hart et al. 2002, Lafrenz et al. 2013, Magilligan et al. 2016, Michel et al. 2011, Stanley et al. 2003). The wide variety of studies conducted across the physical and biological sciences demonstrates both the continued development of knowledge, as well as the fundamental complexity of the processes at hand. Early notable work on dam removal emerging from within the social sciences showed primarily structural and disciplinary approaches to understanding, with informative pieces published in legal journals (Blumm and Erickson 2012) and policy venues (Lowry 2003). Elsewhere, a small but growing number of studies and articles dwelt more broadly on issues of power, politics, discourse and social constructions (see Gosnell and Kelly 2010, Fox et al. 2016, Magilligan et al. 2017).

Still, the relative paucity of work on removals contrasts with significant literature about the broad mosaic of political positions represented, enhanced, and enacted through the construction of large dams and waterworks (see Brooks 2009, McCully 1996, Reisner 1993, White 1996). Political ecology has shown many promising examples of scholarship 
focusing on dams as sites of politically charged conflicts over the environment, changing landscapes, and control of natural resources (see, for instance, Kaika 2006, Sneddon 2015). Simultaneously, the nexus of political ecology and STS has emerged as an important space of inquiry, offering insight into the means by which water-related material technologies_ _things of water management," as Bijker (2007) has put it in another scholarly context—are positioned by politics and do political work (Bichsel 2016, Carrol 2012, Carse 2012, Loftus et al. 2016, Molle et al. 2009, Sneddon and Fox 2011). Kate Meehan's work (2013, 2014) offers compelling insights about the variegated geographies resulting from different apparatus of water provision in Mexico. As she has argued, objects are "full force" in their social or political efficacy (see also Shaw and Meehan 2013).

The bulk of scholarship on dams within critically oriented social sciences has most commonly examine the building of dams and the impacts which stem from their construction (see McCully 1996, Khagram 2004), some recent work notwithstanding (see, for instance, Sneddon 2015). Inherent in my focus on dam removal is the notion that to consider dams as "full force" (Shaw and Meehan 2013), which is to say in real cognizance of their social and political importance and impact, it is worth dwelling on the entire span of their existence. Dam removal — or more generally what is to be done with dams as they age, deteriorate, or grow in obsolescence — poses significant questions about the social and political work of dams. Removal is not a discrete historic and geographic phenomenon, something simply happening at this moment, but a set of interrelated issues that can be studied in concert with, and in the context of dams and their general politics. Simultaneously, there remains the contemporary significance of removals, a key feature 
in comprehending their impacts, effects, and ramifications. The recent frequency of large dam removals in the United States, and elsewhere (see Lejon et al. 2009), provides contextual details and offers some explanation as to the how and why of individual removals.

\section{Environmental Restoration}

Although the present phenomenon of dam removal is necessarily multi-dimensional and multi-causal, involving infrastructural and environment concerns, technology, identity, and aesthetics, the practice and science of environmental restoration has held special sway in contemporary removal projects. Restoration is generally a young field (see Jordan 2010) and it is not uncontested (Lave et al. 2010). As the techniques and understanding of the processes involved with returning to a landscape some of its "prehuman" characteristics have developed in sophistication, critiques have emerged from within and without the field. Clewell and Aronson (2006) demonstrate the social shaping of restoration projects and practice, and describe the values that motivate or drive them. Davis and Slobodkin (2004) argue that "defining restoration goals and objectives is fundamentally a value-based, not scientific, activity" (1). These critiques are in keeping with significant work in science and technology studies and political ecology, which takes to task the entanglement of scientific endeavors and social forces. Forsyth (2002) has notably drawn attention to the "various ways in which environmental science and political processes are mutually embedded" (266), arguing that the line between science and policy (or in this case, science and something more broadly social) is not so distinct. 
Of particular relevance to this analysis is the arguably recursive relationship between environmental restoration and dam removal. In the United States, there has been significant growth in the number of firms with the technical qualifications, experience, and know-how to effectively (in terms of cost and ecology) take part in dam removal projects. Environmental restoration is notable as a field in that private industry has shown a significant amount of influence over the production and dissemination of scientific knowledge (see Lave et al. 2010). While dam removal projects are facilitated by science and technical experience, numerous removals over the past several decades have pushed firms to develop a more robust understanding of to restore or otherwise alter a river within acceptable standards. These suppositions were confirmed in the course of this study, in interviews with practitioners at a leading firm for removal design and engineering.

\section{Science and Technology Studies}

The recursive nature of this relationship (wherein removals have shaped the understanding and knowledge of restoration and this knowledge in turn facilitates restoration) speaks to a novel take on analysis of dam removal, the view of dam removal as a technology. In describing dam removal with respect to this view, I find it helpful to invoke Allenby and Sarewitz's (2011) conceptualization of technology as "cause and effect machines, linking a human intent to a particular consequence via the embedded function of the technology" (36). The technology of dam removal is therefore composed of various practices, techniques, and systems, which facilitate the landscape transformation. This technology is characterized by careful attention to such details as the 
management of sediment, intricacies of habitat design, and revegetation.

The technology of dam removal is specifically a technology of practice, differentiated from material technologies. Microprocessors, automobiles, and the printing press are all easy to recognize as examples of technology, in part because of their material nature. Technologies of practice may lack the same concrete form, but chemotherapy, automobile repair, and bookbinding are all useful examples of technology as practice. Categorizing dam removal as a technology highlights the human and social nature of the intended effects of the technology. Unlike dam failure or collapse, dam removal is intentional, directed, and dependent on specialized skills and knowledge. This categorization also emphasizes the role of expert knowledge of the technology. Lave et al. (2010) demonstrate the power and politics associated with expert knowledge in their analysis of Rosgen methods of river restoration. Their focus on the production of knowledge and role of experts provides a model for my study of dam removal.

Treating removal as a technology also draws attention to the process of translation, where technologies are applied or installed in new settings. Antina Von Schnitzler's work (2013) on electrical and water meters in South Africa highlights the social and political struggles accompanying the implementation of a given technology, in this case prepaid meters, to a new place. Translating a technology to a different social and political context may also involve significant changes to the technology itself. In the case of the San Clemente Dam, the work of bringing dam removal (as a technology of practice) to the Carmel River did not end when the various stakeholders agreed to move forward with removal as a viable option. Instead, the process of translating the 
technology to this next context involved years of negotiations and a myriad of technical adjustments to the process and project.

A corollary to this lens on dam removal is the understanding of the post-removal landscape as an artifact of technology, an intricately planned assembly of "causes" or component parts (rocks, concrete, soils, water) in service of particular (socially or politically determined) "effects," often including the restoration of particular ecosystem functions (see, for instance, Magilligan et al. 2016) as well as social goals (Fox et al. 2016). These social or political goals might include the maintenance of historically significant river features (see, again, Fox et al. 2016), the recovery of threatened or endangered species (see Hatten et al. 2016), or the facilitation of riverine recreation (for a popular example see Gorthy 2018).

This comingling of technology and environment is sympathetic to a more material view of dams as links between nature and infrastructure. The landscapes resulting from a dam's impoundment fall neatly into the rubric of "novel ecosystems" (Hobbes et al. 2009) while the services they render speak to their infrastructural role. The recent proliferation of social studies of infrastructure (see, for example, Crow-Miller et al. 2017) follows older scholarship examining the intertwined roles of nature and infrastructure (White 1996, Cronon 2009, Pritchard 2004). The work of Ashley Carse (2012), who demonstrates the ways in which seemingly "natural" environments are enrolled in projects of infrastructure, holds special relevance.

Studies of this nature stress the varied components of systems of infrastructure. In recent years, a number of related frameworks have emerged or gained popularity, which grapple with the work of numerous human and nonhuman actors in producing, mediating, 
and shaping reality. Actor Network Theory (Latour 2005), Socio-Ecological Systems (Cote and Nightingale 2012), and Jane Bennet's "congregational understanding of agency" $(2009,20)$ all offer a means of exploring interrelationships between seemingly disparate actors, agents, or components. Among these approaches, concepts from environmental history of technology offer particular advantages for conceptualizing dam removal. Specifically, the work of Sarah Pritchard yields the "enviro-technical system" (2011), a flexible, fitting interpretive mechanism utilized in this study.

In Confluence (2011), her environmental history of the Rhone River, Sarah Pritchard articulates a vision for the analysis of an enviro-technical system. Building on Thomas Hughes' concept of the eco-technical environment, Pritchard describes envirotechnical systems as "historically and culturally specific configurations of intertwined 'ecological' and 'technological' systems, which may be composed of artifacts, practices, people, institutions, and ecologies" (19). Pritchard goes on to highlight the porous nature of these systems: elements have a way of finding their way in and out of the system.

Pritchard iterates that the enviro-technical system framework is conceptualized with the "enviro-technical regime," which emphasizes the historically contingent (and ultimately political) development of the system. The regime reminds us that the conditions, components, and attributes of a system do not merely exist, nor do they simply arise, but they are the result of specific, interrelated (though not always proximate) events and shaping-forces operating on sometimes-broad timescales. This is not to argue that the differing frameworks or terms in the nexus of systems/networks/assemblages have failed to take a historical view. Even within the microcosm of studies involving water and infrastructure, but nominally considered 
outside the discipline of environmental history, there exist a notable variety of strong scholarly contributions taking a historic perspective (see, for example, Sneddon 2015 , Berry 2014). Rather, the enviro-technical regime is pertinent in that it places emphasis on historic contingency, implying that a snapshot perspective of the network is as limiting as a perspective that assumes that the system is closed. Concurrently, the regime precludes deductions or conclusions that might consider the "final" stage of the system to be a teleological endpoint.

Social history of technology, and STS more generally, is replete with examples of the contingency of present networks. Thomas Parker Hughes (1993) and Weibe Bijker (2007), offer compelling examples of this, demonstrating that technology does not merely come into being, but is constantly shaped and remade. Elsewhere, the historical literature has focused on the intertwined roles that technology and the environment occupy in the co-production of present environmental conditions, socio-natures, and novel landscapes (Evenden 2004, White 1996). Dams, and their removal, demand a similar, perhaps heightened attention to historic contingency, time, and the specific regimes into and by which they were constructed. As Chris Sneddon reminds us "every large dam erected in the twentieth century has a socioecological and ideological influence that far outlives the expertise and political aims that produced it" $(2015,18-19)$. In other words, dams, particularly large dams, exist on timescales that outlast human lives and, perhaps, the systems into which they were built.

This ability for dams to translocate values and politics through time speaks to obduracy, a key concept from STS that informs my analysis of the San Clemente dam removal. Conceptually, obduracy describes resistance to change as manifest in a 
technological artifact or system, as well as the means by which those same artifacts and systems translate social values through time (Bijker 1997). This second characteristic of obduracy is described by Bruno Latour (1992) in his discussion of the "hardness" of objects. His work is echoed in part by Hughes (1987) who argues that "durable physical artifacts project into the future the socially constructed characteristics acquired in the past when they were designed" (77). These artifacts, written with politics, are also resistant to change. For example, Langdon Winner (1980) describes overpasses, designed by Robert Moses in New York, that cross over parkways leading to certain beaches on Long Island. That these overpasses were designed low enough so as to prevent busses, and hence the social classes that depend on them, from reaching the beach is taken as an explicitly political act. Not only do the overpasses enact a particular political vision, but they also remain a difficult-to-change, obdurate component of New York's transportation infrastructure.

While Winner's take on Moses has been contested over the decades since it was first published, it nevertheless illustrates the work enacted through obdurate objects and their effects upon the world. Concerning the "how" of obduracy, Anique Hommels (2005) describes a debate between theorists of obduracy on whether it (obduracy) emerges as it is "deliberately built into artifacts" (336) or is the result of an artifact's embeddedness in a network or system. For the purposes of this analysis, I focus on the latter supposition, the ways in which systemic entanglements and interactions contribute to the immovability of other system components. Following this, dams resist removal in part due to their materiality, but also because of the vast enviro-technical systems in which they come to occupy pivotal (and sometimes unplanned) roles. 
The work of obdurate objects speaks to a second, related idea from STS, namely the concept of techno-politics. Although often associated with the work of Timothy Mitchell (2002), techno-politics, as an analytical and theoretical approach, has been indelibly shaped by the work of Gabrielle Hecht who describes the concept (techno-politics) as "[T] he strategic practice of designing or using technology to constitute, embody, or enact political goals" $(2001,256)$. For the purposes of my analysis, and indeed anywhere human motives are obscured or difficult to discern, I argue that the strategic element need not be apparent, nor an object of concern. Mitchell's work, while invoking a similar interest in the political outcomes of purportedly value-neutral work, tends to dwell more on practice and techniques, as opposed to the more material conception offered by Hecht. Considering dams and dam removal, the present value of the concept is then in its ability to innately connect politics to material, nonhuman things (as artifacts of technology). 


\section{$\underline{\text { Methods }}$}

This study used a mixed, qualitative methodological approach to examine the work of politics in and through the removal of the San Clemente Dam. In particular, I employed semi-structured interviews, discourse analysis, as well as archival research and document analysis. In what follows, I describe the initial research design and subsequent adjustments, which coalesced in the final design, study, and analysis. While the methodological approach of my study was updated from the original proposed design, the central, guiding research questions (as described above) remain consistent.

The initial design of this study included a focus on discourse analysis, to be performed on the results of semi-structured interviews as well as archival documents related to the removal project. Specifically, I was interested in examining the “technological frames" (see Bijker 1997) of various actors, and subsequently, intended to employ discourse analysis to understand the logic and narratives inherent to distinct frames. These concerns and interests are represented in the secondary research questions of this study: how are politics represented in the discourses surrounding the removal of the San Clemente Dam? And how did these political discourses shape or enable the dam removal project?

While the concept of the technological frame offers some methodological and analytical utility, it became quickly apparent, upon commencing the actual research process, that the goal of identifying, analyzing, and explaining the existence of multiple, hypothetically discrete technological frames would overwhelm any available resources of time and attention, and necessitate a deep, comprehensive understanding of the removal, its lead-up and the enviro-technical system within which it occurred. This realization 
represents a key flaw in the research design, specifically that the number of interviews and time allotted to complete the project would not allow for a rigorous understanding of the particular perspectives taken by various parties on what often proved to be highly technical matters. In light of these realizations, the study design was then altered so that the technological frame was no longer a critical object of analysis.

In conjuncture with an attention to discourse analysis and the aforementioned research questions, the initial research design also centered on understanding the ways or means by which politics are embedded in the post-removal landscape. This concern compelled me to look at different parties and stakeholders, and to work towards identifying how the post-removal landscape was shaped by negotiations, management of power, politics, and the power-laden ends to which it contributes. Overall, the secondary research question directed towards these issues (what are the politics embedded in the post-removal landscape?) necessitated a similarly robust understanding of local politics represented (as above) in theoretical terms by the enviro-technical system, as outlined in my literature review.

Although discourse analysis nevertheless plays a role in the analysis and conclusions of this study, the work of documenting and explaining the functional role of politics throughout the project took an outsized role. This shift in focus (in more detail below) occurred in response to my realizations of the limits and study and presuppositions built into the research design, as well as compelling direction taken from the data itself.

In order to analyze discourses and gain a more robust knowledge of the removal project, the initial study design called for the collection of relevant documents, reports, 
and publications related to the removal. These collected documents were to have included those from before, during, and after the removal process. Although the post-removal period is likely a significant timespan for understanding the ramifications of the project, the abundance and richness of available information, in concert with the complexity of the project, prompted my decision to focus exclusively on documents produced in the time periods preceding and concurrent with removal. My general understanding of the San Clemente Dam Removal was bolstered and strengthened by studying dozens of historical reports, letters, meeting minutes, and similar documents. All told, I collected and consulted approximately 50 documents. Among these, I cite several (including environmental impact reports) in this study. The original study design called for the consideration of a wide range of documents produced by parties affected by or involved with the removal. In practice, the majority of relevant documents, and those of the most apparent analytic utility, consisted of government reports and memorandums.

Following the collection of documents, my initial study design called for the development of a coding scheme in order analyze and code the information contained in the relevant documents. This process was intended to contribute to the identification and analysis of latent content in the form of discourses and narratives. Adapting to time constraints and the merging complexity of the removal story, the documents were instead used in constructing a history of events, contributing to an understanding and illumination of relevant interactions between actors and stakeholders.

The analysis this process lends itself towards is, admittedly, less attentive to the inter-relationships and co-production of knowledge and power (typical objects of attention in discourse analysis). Rather, it takes a more functional perspective on power 
and politics, relying on a less problematized version of events and portrayal of removal proceedings. The analytical benefit of this is adjustment is, I maintain, an overall more robust understanding of the events, actors, and processes that comprise the envirotechnical system and regime.

My initial proposal called for interviews with six to ten participants. I drafted a list of questions and follow-up questions to guide the interview. Each question was intended to elucidate or encourage information on a specific primary or secondary research question. In the initial design, research subjects were to have been selected as they corresponded to three general groups; private interests, public interests, and oppositional interests (those who opposed the project). The subjects were to have been located and identified using a snowball sample technique, where existing contacts recommended or indicate additional subjects (Hay 2005, 72).

During the fieldwork process I completed seven semi-structured interviews, using the interview guide (see Appendix). Each interview lasted approximately one hour, with several ending after close to two hours. I also made a number of personal communications (unrecorded) with acquaintances familiar with the San Clemente project. All interviews were recorded and transcribed to facilitate analysis. The subjects I spoke with included individuals such as a community member with a deep knowledge of pertinent issues; the representative of a local non-governmental organization connected to the Carmel River and the San Clemente Dam; representatives from local, state, and federal agencies (all of whom collaborated on the project); and a fisheries biologist who worked on this and similar projects. In order to protect anonymity, personal details of the interview subjects have largely been omitted from my writing. In the pursuit of a 
representative sample, I also requested an interview with a representative of the dam owner (California American Water), but my request was respectfully denied. This resulted in a key, missing voice in the final analysis.

While my initial plan for categorizing interview subjects (public, private, and oppositional interests) was somewhat useful for identifying stakeholders, the task of categorizing interview subjects grew in complexity as details of the project emerged. For instance, several subjects had overlapping connections to the project (as government employees and local residents). Similarly, there was little direct, vocal opposition to the removal of the dam itself (although some locals temporarily voiced frustration at truck traffic during the removal process). Moreover, alliances or connections between stakeholder groups shifted throughout the removal process. This was most clearly demonstrated through the project team, composed of California American Water (Cal Am), the California State Coastal Conservancy, and National Marine Fisheries Service (NMFS). Whereas Cal Am and NMFS were formerly of an adversarial relationship regarding the dam and impacts of impoundments to anadromous fish, the two stakeholders later collaborated on the removal as part of the project team. Indeed, the project team, as a public-private partnership (blurring the lines between my public and private interest categories), often experienced its most significant resistance from other government agencies (public interests). 
Table 1

Interview Subjects

\begin{tabular}{|c|l|}
\hline$\underline{\text { Role }}$ & Number of Subjects \\
Government employee & 4 \\
Local resident & 1 \\
Non-governmental agency representative & 1 \\
Employee of private firm involved with removal & 1 \\
\hline
\end{tabular}

As with the document analysis, my focus in the analysis of these interviews shifted to their utility in documenting and explaining the actions and motivations of various actors. Information and quotes gathered from the transcripts add depth and elucidate positions and positionality not necessarily visible in available descriptions of the project, or in the government documents I collected. So, while discourse analysis remained a component of my interview-analysis process, the main contribution of these transcripts was in documenting the "what" of political machinations, rather than the "how" which might be explained through a more in-depth focus on discourse and narrative. The experiences and perspectives related by my interview subjects proved invaluable in understanding and shaping explanation of my investigations into the agency of various components of the enviro-technical system. 


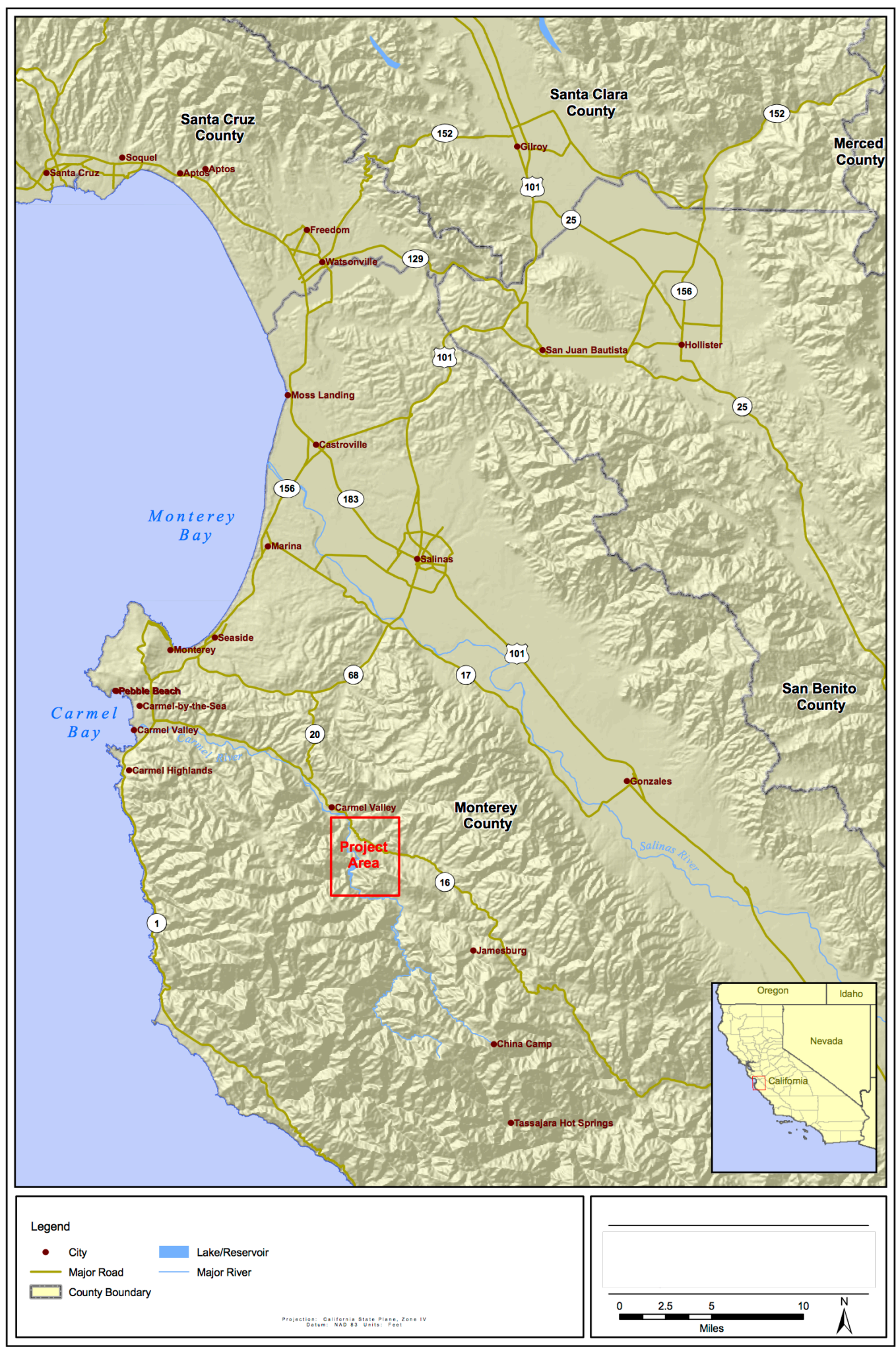

Figure 1. Adapted map of the region and project area (California Department of Water Resources 2012). 


\section{History and Analysis}

\section{Case Study}

The primary case study for this analysis is the removal of the San Clemente Dam near Monterey, California. The dam, which stood 106 feet tall and (at least initially) impounded some 1,500 acre feet of water on the Carmel River, was the largest such structure ever removed in the state of California. Although the removal project, officially dubbed the Carmel River Reroute and Dam Removal, compared in cost and magnitude to other recent removals of high dams, the media attention it received was relatively minimal. This lack of attention is perhaps not all that unusual, but given the magnitude of the project, the novelty of the engineering involved, and the complex character of the region and landscape from which the dam was removed, the story makes a compelling site to examine these issues.

Flowing some 36 miles, the Carmel River originates in the Santa Lucia Mountains of the California Coastal Range and empties into the Pacific Ocean in Carmel Bay, at the southern end of the Monterey Peninsula. For over two centuries, and perhaps a great while longer than that, the river has been the primary water source for communities on the peninsula and has supported the growth of its industries over time. Although a number of small dams and diversions have been built on the river, the dominant structures were the San Clemente Dam (now gone) and the Los Padres Dam (still there, farther upstream). Both dams were constructed to provide water to support population growth, tourism, and the sardine industry, made famous in John Steinbeck's Cannery Row (1945/1994). The municipal water supply of the Monterey Peninsula, including the communities of Carmel and Monterey, is currently provided by California American 
Water Company (Cal Am), an investor-owned utility and a subsidiary of American Water. Cal Am purchased most of its Monterey Peninsula water rights and infrastructure, including the San Clemente Dam, from another private utility in 1966.

In what follows, I describe and explicate the enviro-technical system into which the San Clemente Dam was built, and into which it became an integral, physical component. By the time the dam was a candidate for removal, it had become thoroughly enmeshed in a complex, porous system and presented distinct challenges for advocates of removal. During the period from 1980 until 2015, throughout which time a dynamic coalition advocated for and executed the dam's removal (overcoming its pronounced obduracy), political and social interests indelibly shaped the removal process and the eventual physical outcome. 


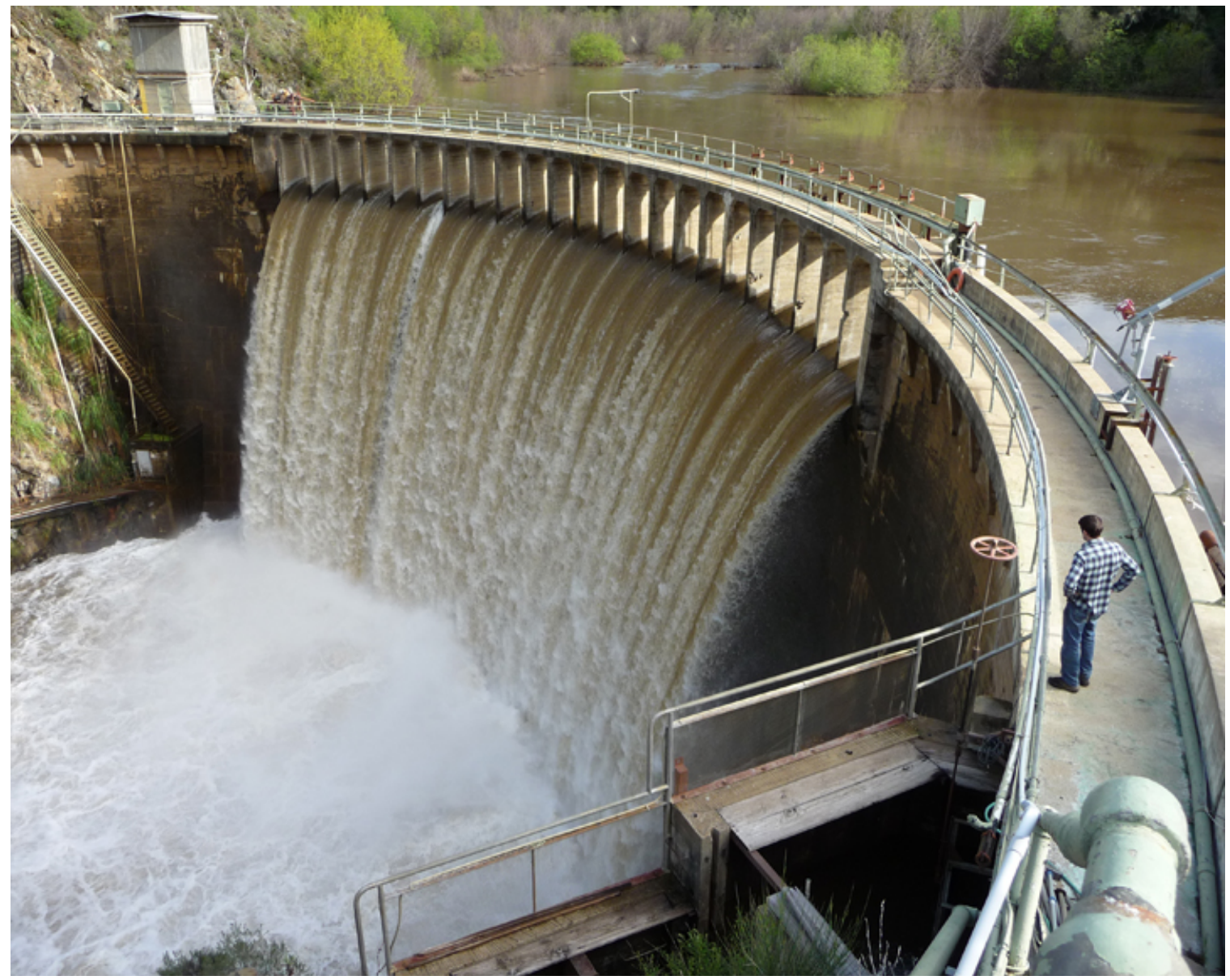

Figure 2. Photograph of the San Clemente Dam prior to removal (California American Water n.d.).

\section{Outlining the System}

For 94 years, the San Clemente Dam obstructed the Carmel River, its concrete arch impounding a large, once-deep reservoir and, over time, accumulating a startling mass of sediment. During those decades, its presence indelibly shaped the greater region it was built to serve-materially, politically, and ecologically. In its service life and beyond, the dam comprised a sometimes-integral position with a historically contingent system of environmental, technical, social and political components.

While the removal of the dam (from the landscape and the system) is at the heart 
of this study, the politics of removal, and the means by which the practice of dam removal came to this particular location, are both historically situated. In the following subsection, I trace the pre-existing political context and enviro-technical system within which the removal came to be.

This is not a complete history of the San Clemente dam or the region, but a presentation of particular vignettes or episodes that serve to illustrate changes to or alterations in the system. As an analytic framework, the enviro-technical system helps to focus the analysis on relevant factors of phenomena, but even within the system there must be elements which remain beyond analysis. The story that emerges is intended less to fully capture the enviro-technical system surrounding the San Clemente Dam, but rather to reflect and highlight the elements of it that proved most pertinent and telling within the context of the dam's removal.

The enviro-technical system within which the removal occurred is composed of a multitude of distinct actors. Broadly speaking, agencies, interest groups, the local municipal water system, and private individuals connected to the Carmel River are linked within the system. Key players in the contemporary system include the Monterey Peninsula Water Management District (MPWMD), the dam owner (California American Water), and government agencies with mandates connected to the river and surrounding area including the California State Coastal Conservancy (SCC), the National Marine Fisheries Service (NMFS), and Monterey County Planning Department.

As the removal project progressed, actors from a wider geographic sphere, most pertinently NMFS and SCC, became integral to the composition of the system and changes therein. Throughout the removal process, the specific, spatial boundaries of the 
enviro-technical system retained relative clarity. Generally speaking the removal involved or affected three distinct, overlapping geographic areas.

First, the removal concerned the Carmel River ecosystem and riparian corridor. In general, dam removal has distinct up- and downstream ramifications, primarily characterized by altered or adjusted flow regimes (Stanley and Doyle 2003), channel morphology (Doyle et al. 2003), sediment transport (Pizzuto 2002), riparian vegetation (Shafroth et al. 2002), and biotic connectivity (Magilligan et al. 2016). Given this multiplicity of effects, the entire river corridor is subject, in varying measure, to changes subsequent to dam removal.

The region and municipalities that rely on the river and water it transports for environmental services define a second geographic scale for the enviro-technical system. Relevant ecological services here include habitat for anadromous fish species (particularly steelhead trout), recreational interests in the surrounding environment, and most pertinently, provision of drinking water to the Monterey Peninsula. The Carmel River is the primary municipal water source for a distinct geographic region in the area, which comprises a key geographic boundary for the analysis in this study.

Finally, the removal directly involves areas immediately proximal to the dam site. Although they are situated outside of the river corridor and are not connected to the river's municipal-water-provision function, small communities (namely Sleepy Hollow and Cachagua) located near or en route to the dam site were directly affected by its removal, owing to the construction projects involved with removing the dam and rerouting the river.

The Monterey Peninsula sits approximately 100 miles south of San Francisco, 
along California's central coast. Population estimates vary, depending on how one defines the "peninsula," and which portions of its principle communities of Monterey, Carmel-by-the-Sea, Seaside, and Pacific Grove are included in the estimates. The Monterey Peninsula Water Management District, which oversees the allocation and management of water resources for much of the region, counts approximately 100,000 individuals as its direct constituents, and although this figure does not entirely reflect the regional population, it is a useful representation of population tied into the region's waterscape (Monterey Peninsula Water Management District n.d.).

Much of the literature on water and water systems in California has focused on the large, interconnected networks that span the state (see Hundley 1992, Worster 1985) and draw from watersheds originating as far away as Wyoming (Reisner 1993). In contrast, the Monterey Peninsula is for most purposes effectively isolated, remaining unconnected to the broader technical infrastructure systems in the region and state. The Carmel River is the region's primary water source - approximately seventy percent of the its municipal water supply comes from the California American Water Company's wells on the lower river, with the remaining thirty percent coming from the upstream Los Padres Reservoir, diversion at San Clemente reservoir (recently eliminated), and the Seaside Basin (California American Water 2009). The region's high degree of dependence on a single stream is notable in California, particularly given the complex, interconnected infrastructure that serves many other regions within the state. There are analogous configurations within the state (see for instance, the Sonoma County Water Agency's dependence on the Russian River and Eel River watersheds), but peninsula's reliance on a single water source, coupled with its relatively high level of development 
and proximity to agricultural, appears generally singular.

The Monterey Peninsula Water Management District, which oversees local water resources in the region represents California's legacy of local, decentralized government managerial bodies which began with the passage of the 1887 Wright Act (Hundley 1992). The Wright Act authorized the implementation of local irrigation districts, creating a model that was followed by a number of local government districts in the state, some of which, like the MPWMD, explicitly managed municipal water supplies. Following significant drought and water shortages, the Monterey Peninsula Water Management District was assembled in 1978 as a direct response to fish die-offs (particularly steelhead) and the general degradation of the Carmel River watershed due to California American Water Company's pumping of water from the river to fulfill its municipal needs (March 2012, 101). The district was formed largely to provide oversight regarding water allocation in the region and to prevent further water shortages like those experienced in 1978, wherein the appropriative rights (see Hundley 1992, Worster 1985) of the water company conflicted with both public goods (the river ecosystem) and the riparian rights held by landowners along the river.

The formation of the MPWMD, and the conflicts it dealt with, were an outgrowth of the legacy of water development in the region. The Carmel River had served its function of water provision since the first European settlements were established in the area, and realistically much longer, given indigenous settlements in the region. But the modern historical legacy surrounding the river is marked by the touristic and real estate development that began in the region towards the end of the 19th century. This history traces a development strategy that shaped the region and tied local municipalities to the 
Carmel River.

In 1880, the Pacific Improvement Company began work on its soon-to-be-wellknown Hotel Del Monte - a project demonstrating the new regional development strategy that used tourism to drive residential growth (March 2012, Chiang 2009). The Del Monte project necessitated the building of the first dam on the Carmel River, the "Old Carmel Dam," and laid the foundations, in some cases literally, for the region's water infrastructure (Chiang 2009 26). In addition to supplying water to Hotel Del Monte, the Pacific Improvement Company used their Carmel River diversions to supply water to new housing developments in the late 1800s and early 20th century. In 1905, the Pacific Improvement Company created the Monterey County Water Works (MCWW) as a subsidiary company in possession of the parent company's various water works and infrastructure.

Continuing this legacy of private service provision, the Pacific Improvement company sold MCWW to the Del Monte Properties Company in 1919 (March 2012, JRP Historical Consulting 2014). Immediately thereafter, in order to further regional development and home sales, MCWW began their pursuit of a larger dam on the Carmel River. Construction was completed on the 106-foot San Clemente dam in 1921 which, until the larger Los Padres Dam was constructed upstream in 1949, served as the infrastructural centerpiece for local water provision in the region (March 2012, JRP Historical Consulting 2014). MCWW's water infrastructure, including the San Clemente dam, changed hands in 1935 and again in 1966, when the dam was purchased by California American Water Works (Cal Am), a newly minted division of American Water Works. 


\begin{tabular}{|c|l|}
\hline \multicolumn{2}{|l|}{ Table 2} \\
San Clemente Dam Timeline \\
\hline$\underline{\text { Year }}$ & $\underline{\text { Event }}$ \\
1880 & Hotel Del Monte construction \\
1921 & San Clemente Dam completed \\
1966 & California American Water purchases San Clemente Dam (and other assets) \\
1972 & Dormandy Airstrip \\
1977 & Marble Cone Fire \\
1982 & First surveys completed for DSOD \\
1992 & WCC report finds structural liabilities \\
1997 & Steelhead listed as threatened species \\
1999 & Kirk Complex fire \\
2006 & Recirculated Draft EIR includes reroute and removal option \\
2007 & State Coastal Conservancy involvement \\
2010 & Collaboration statement signed between parties and project team \\
2012 & CPUC approves reroute and removal project \\
2013 & Removal construction begins \\
2015 & Removal complete \\
\hline
\end{tabular}

Dams naturally accumulate sediment, which would otherwise pass downstream unobstructed. Over its service life, the San Clemente Dam was subject to this geomorphic process. Additionally, the regular sediment accumulation of the San Clemente Dam was amplified by a number of critical events that caused the deposit of significant amounts of sediment. The Marble Cone Fire (1977) and the Kirk Complex Fire (1999) have both been pointed to as events that caused significant amounts of sediment to be swept into the river. Similarly, in 1972, a private individual constructed the Dormandy Airstrip on their property, which led to landslides that caused a significant volume of sediment to wash into the river and accumulate behind the San Clemente Dam (California Public Utilities 
Commission 2012). This accumulation of sediment would eventually become a key factor in the dam's fate.

\section{Lead-up to Removal}

By 1980, the San Clemente Dam was an artifact of declining utility, although the dam and impoundment would continue as an active component in water provision for another 22 years. Sedimentation and the rapid infilling of the reservoir had become obvious decades before (Monterey Peninsula Water Management District 1989), and the significant increases in sediment resulting from the Marble Cone Fire and the Dormandy Airstrip had demonstrated the material consequences of individual events on the functionality of the dam. By 2015 (California Department of Water Resources 2012), the reservoir that once boasted a storage capacity some 1500 acre-feet of water, was only capable of impounding five percent of its original volume. And yet, in spite of the dam's clear and impending uselessness due to its manifold sedimentation issues, it was ultimately the threat of earthquakes and floods that first precipitated a consideration of what was to be done with the San Clemente Dam.

When construction of the San Clemente Dam began in 1919, the owner/operator (then the Pacific Improvement Company) was minimally regulated with regard to permitting or formal governance. During its service life, the dam and its operators became subject to modern oversight, and decisions about the dam that became the purview of government authorities at multiple scales that were not necessarily present in the original enviro-technical system. Ultimately, the removal was fundamentally shaped by three key agencies, which often exhibited overlapping, contrary mandates - the 
California Department of Water Resources Division of Dam Safety, the California Public Utilities Commission Division of Ratepayer Advocates, and the National Marine Fisheries Service. In addition to those three organizations, the California Department of Fish and Wildlife (formerly Fish and Game), The Monterey Peninsula Water Management District, the US Fish and Wildlife Service, the US Army Corps of Engineers, and the Monterey County Planning Commission also exercised jurisdictional responsibility and shaped the dam removal process.

The first actions leading towards the removal of the San Clemente Dam began in 1980, when the California Department of Water Resources Division of Safety of Damns (DOSD) ordered California American Water to conduct surveys regarding the dam's capacity to pass and withstand a Probable Maximum Flood (PMF) or Maximum Credible Earthquake (MCE) (California Public Utilities Commission 2012). Cal Am hired a contractor to complete the required analysis, which was first submitted to the DOSD in 1982 and indicated the dam's structural soundness in either event. Over the next six years, the DOSD continued to request additional analyses. During this same period, the Monterey Peninsula Water Management District pursued the construction of a new, larger dam on the river (the "New San Clemente Project"), which would inundate the original San Clemente Dam. The DOSD agreed to defer their requests for further analysis on the San Clemente (California Department of Water Resources 2012) while the new construction project was being explored.

Bowing in part to the public's concerns over negative environmental outcomes, the MPWMD canceled plans for the New San Clemente Project in 1989. With the San Clemente Dam no longer facing inundation, the DOSD requested an updated analysis of 
the structure with respect to MCE and PMF, resulting in the 1992 report "The Seismic and Flood Stability Evaluation, San Clemente Dam" (Woodward-Clyde Consultants 1992). This report demonstrated significant structural liabilities and prompted the DOSD to require that Cal Am bring the dam into compliance with current safety standards (California Department of Water Resources \& US Army Corps of Engineers 2012). Significantly, the report found that the dam was likely to collapse in the event of a 7.0 earthquake on the nearby Tularcitos Fault (CDWR \& USACE 2008) and be overtopped by 14 feet of water in the event of the maximum probable flood. Either event would pose significant risk to the area's residents and 1500+ homes located downstream of the dam (California Department of Water Resources 2012).

Multiple subjects interviewed in the course of this study indicated that throughout the early 1990s, both Cal Am and the DOSD were in favor of non-removal options, as evidenced by multiple reports produced during that time. Indeed, the 1998 first Draft EIR prepared by the DOSD did not include dam removal as one of the proposed options (see California Public Utilities Commission 2012). DOSD released three subsequent draft environmental impact reports that also did not consider removal. While Cal Am continued to advocate for reinforcing or "buttressing" the dam, NMFS began (according to interview subjects) to apply pressure to consider removal as an option.

During this time period, two species in the Carmel River ecosystem were listed as threatened under the Endangered Species Act: the California Red-Legged Frog in 1996 and the South-Central California Coast Steelhead Evolutionarily Significant Unit in 1997. Under Section 7 of the Endangered Species Act, NMFS is charged with assessing the potential impacts resulting from projects undertaken or permitted by other federal 
agencies with regard to threatened marine species. In this instance, Cal Am was required to obtain a Section 404 Permit, under the Clean Water Act, from the US Army Corps of Engineers. Interview subjects reported that, in advocating for the inclusion of removal as a viable option for the San Clemente Dam, NMFS threatened to issue a jeopardy opinion on the impacts of buttressing - indicating that the project would have a profound, negative impact on local steelhead and halting any progress on addressing the dam. During interviews, one NMFS official shared that "you know, the run probably would have been wiped out if [the dam] had stayed in, so it just seemed like a no-brainer." Addressing concerns and issues in the original Draft EIR, the DOSD issued a second EIR in 2000 (the Recirculated Draft EIR or RDEIR), but following further criticism in the form of public and agency comments, the DOSD withdrew this RDEIR in 2002 (California Public Utilities Commission 2012). Bowing to pressure from NMFS (among others advocating for removal), the DOSD began a combined EIR/EIS process with USACE and, for the first time, included dam removal during the "scoping process'. In 2006, the DOSD complete The San Clemente Dam Seismic Safety Project Draft EIR/EIS, which include the Carmel River Reroute and Dam Removal as an option for addressing the seismic and flood risks of the dam.

After the latest EIR/EIS was released, the California State Coastal Conservancy began to directly involve themselves in the San Clemente project. Mandated with providing technical and financial assistance to projects intended to enhance or protect California's coastline, and having previously funded studies on dam removal, the conservancy began to work on San Clemente project as an advocate for removal, and in 2007 , funded $\$ 700,000$ worth of studies to evaluate the removal option (California Public 
Utilities Commission 2012).

One interview subject, a government official deeply involved with this stage of the process and an advocate for the removal and reroute option, shared that, although the reroute option had been included in the 2006 Draft EIR/EIS, it still had less-thanuniversal support, from Cal Am and, more pertinently, the firm hired to work on the EIR. They stated that:

The consultants that did the engineering for the EIR, they were pretty firm on the project is going to be dam-strengthening. But they were the ones that had done the preliminary design for the reroute project...

The firm referenced above was later hired to write a basis of design report, which would further explain and expand on the engineering information contained in the original EIR. The interview subject quoted above explained that this basis-of-design report (MWH Americas 2008) illuminated a continued recalcitrance towards removal that was indicative of a preference for buttressing.

And it was kind of in that process that I really learned how reluctant they were, I mean, they just they just didn't take the dam removal seriously. A lot of people didn't for a while.

Several additional interview subjects described an ensuing period of intense negotiations, challenges, and bureaucratic machinations that unfolded in light of this resistance towards removal. A number of design, restoration, and engineering firms were consulted at different stages of the process because of their expertise in dam removal, but also, reportedly, because of their propensity towards it. As reported by several interview subjects, the efforts towards removal, directly countered pressure from the DOSD to finish the project via buttressing, and therefore mitigate the risks of dam failure, as quickly as possible. 
During this same time frame, the SCC and NMFS were reportedly collaborating on means to secure funding for the reroute and removal project. Although some of the particulars of funding are discussed in subsequent sections, it is relevant to point out that the final organization of funding and funding sources was partly the result of calculated decisions by proponents of removal — namely, the SCC and NMFS. These organizations were committed to funding any costs of removal that exceeded the $\$ 49,000,000$ buttressing effort estimate made by $\mathrm{Cal} \mathrm{Am}$.

With the removal and reroute option included in the 2008 Final EIR/EIS (CDWR \& USACE 2008) and a portion of the funding puzzle completed and on the table, 12 organizations signed an agreement indicating support and collaboration on the removal and reroute option (California American Water 2010). The planned reroute accomplished three, related goals: it mitigated the risks associated with dam failure; it provided a purportedly advantageous alternative for endangered species and enhanced watershed connectivity (critical for anadromous steelhead); and it provided a socially, fiscally, and politically viable solution for the 2.5 million cubic yards of sediment which had accumulated behind the dam. 


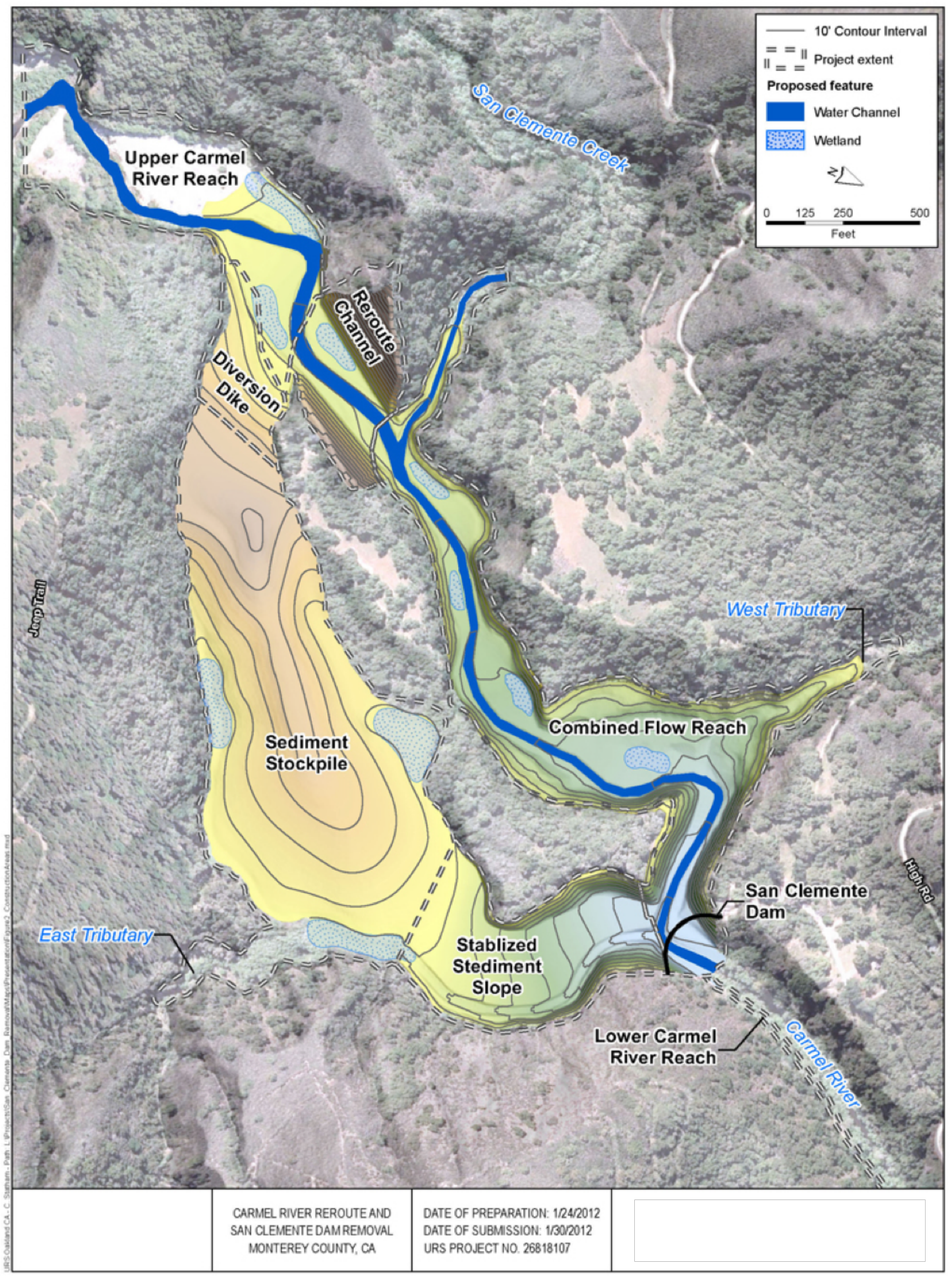

Figure 3. Adapted reroute project map (California American Water n.d.). 


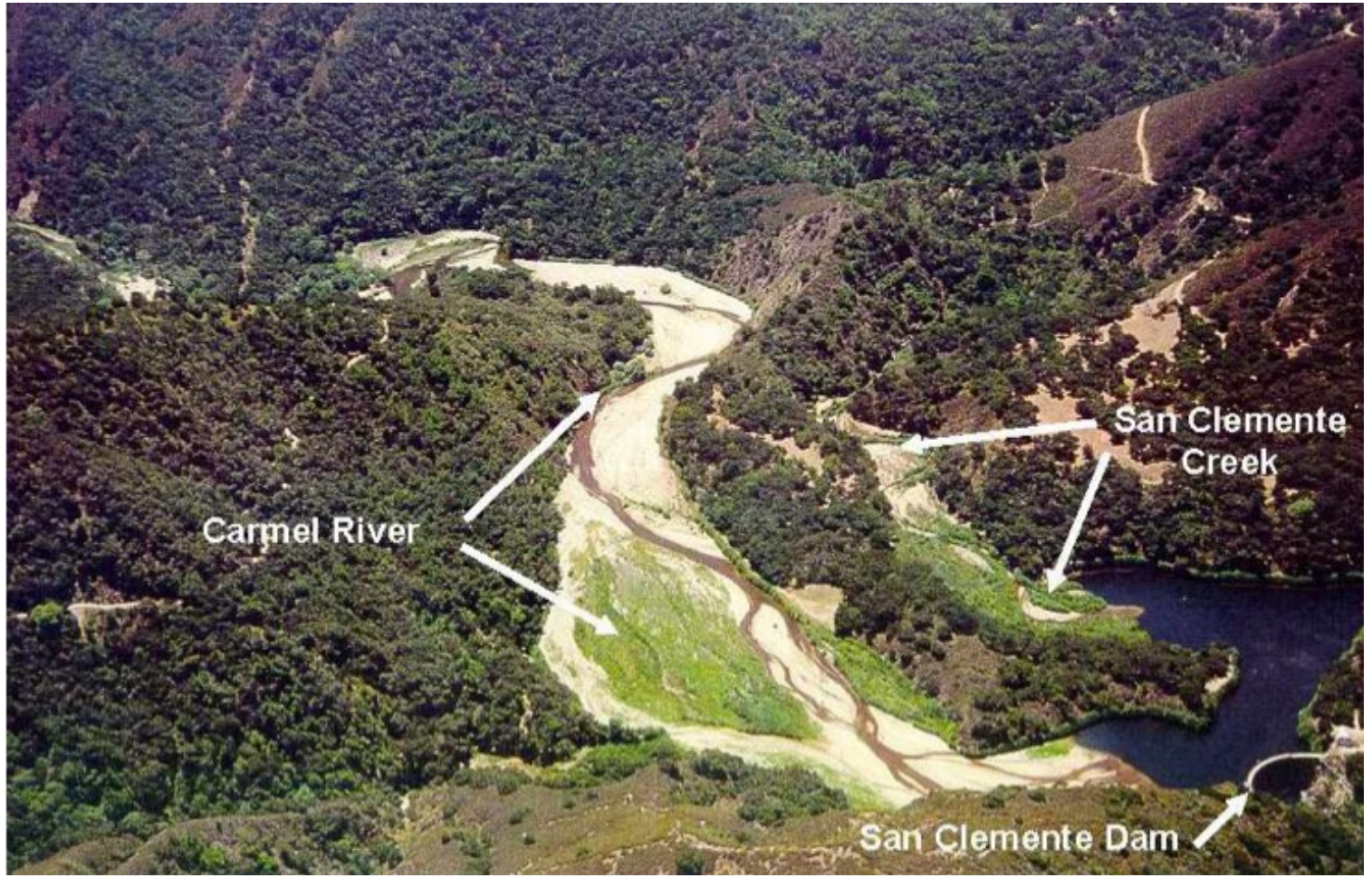

Figure 4. Aerial photo of project site showing reservoir and sediment accumulation (California State Coastal Conservancy n.d.).

\section{Funding}

In the course of my interviews, I asked participants to talk about how the removal was funded. Responses ranged from detailed discussions of the mechanisms by which funding was secured to broader, speculative commentary on responsibility and who, ultimately, should pay for such projects. Some interview subjects, particularly those associated with the removal project team, pointed to the orchestration and management of funding issues as a key success in the project, indicating that there were significant hurdles in finding and raising sufficient funds, as well as in assuaging concerns and addressing mandates of particular agencies. Others expressed a pronounced, dim view of the funding outcomes (who eventually paid for the removal), generally linking these concerns to larger issues around local water, utilities, and ongoing political conflict. 
One subject, a government engineer involved with the project nearly from the beginning, pointed out an issue at the heart of removal — that in general, dams are built without a plan for the end of their service life - an issue that encompasses the particulars of the San Clemente case. Like other artifacts of infrastructure, dams project into the future not only their inherent purpose or politics, but a looming burden, in this case financial, and unanswered questions regarding how to deal with them when the envirotechnical system within which they once functioned has changed or been changed to the point that the artifact no longer functions. As this subject posited:

I mean there should be a mechanism to fund decommissioning or to fund some kind of maintenance for the facility. Otherwise you're allowing the people today to benefit from that facility and the people tomorrow have to pay for the cost of dealing with it which isn't fair. It's saddling future generations with the cost of the what the older generation got a benefit from. So, there's some unfair practices in my opinion going on as far as funding the maintenance and eventual decommissioning.

The issues the engineer is explaining — that the ostensible lack of a funding mechanism in a well-regulated utility and governmental context has certain consequences-composed some of the more significant challenges the project team (Cal Am, SCC, and NMFS) faced in working towards the removal and reroute.

In more general terms, the myriad of financial and funding-related questions speaks to the challenges of adapting or translating the technology of dam removal to the San Clemente context, with its attendant enviro-technical system and regime. While the biogeophysical realities of the river corridor, ecosystem, and landscape shaped the material design of the removal and reroute, so too did the human, political, and governmental dimensions determine the particularities of how removal technology was translated to the San Clemente Dam site. 
Another perspective on removal funding and financing issues calls for consideration of the ways in which funding represents a component of the dam's obduracy. While the dam's physical mass contributed to the challenge of pulling it down, both with respect to work expended to remove it, as well as the financial costs of any alteration to the structure, so too did the dam's situatedness within a complex system of governance and a historically contingent enviro-technical system. The dam's active entanglement in a political network contributed to what Jane Bennet has referred to as the "negative power or recalcitrance of material things" $(2009,1)$.

In the end, the total cost of the removal and reroute project amounted to $\$ 83,133,000$, with Cal Am bearing $\$ 49,000,000$ (California American Water n.d.). The rest of the costs of funding the removal are broken down in Table 3, below:

\begin{tabular}{|c|c|c|c|}
\hline $\begin{array}{l}\text { Table } 3 \\
\text { Project Costs and Fui }\end{array}$ & & & \\
\hline Organization & Type of Organization & Contribution & Percent of Total \\
\hline $\mathrm{Cal} \mathrm{Am}$ & Private Corporation & $\$ 49,000,000$ & 58.94 \\
\hline State of California & Government & $\$ 28,200,000$ & 33.92 \\
\hline Federal Government & Government & $\$ 2,500,000$ & 3.01 \\
\hline Settlement Funds & Private Corporation ( $\mathrm{Cal} \mathrm{Am})$ & $\$ 2,000,000$ & 2.41 \\
\hline The Nature Conservancy & Non-Governmental & $\$ 1,000,000$ & 1.2 \\
\hline Resources Legacy Fund & Non-Governmental & $\$ 433,000$ & .52 \\
\hline
\end{tabular}

California American Water n.d.

Contributions from two non-governmental organizations, the Nature Conservancy and Resources Legacy Fund represent overlap between these organizations' missions and the ecological benefits of dam removal. The $\$ 2,000,000$ in settlement funds came from 
Cal Am (separate from their $\$ 49,000,000$ project costs), as a result of lawsuits over Cal Am's detrimental pumping, diversions, and dewatering of the Carmel River. This settlement mandated that $\$ 3,500,000$ was allocated immediately for projects benefitting steelhead, with an additional $\$ 1,100,000$ paid annually (California American Water and National Marine Fisheries Service 2006).

Although the settlement funds comprised a small portion of the project's overall funding, they nevertheless illustrate the means by which legacies of resource use, conservation, and conflicts over water shaped and influenced the removal of the San Clemente Dam. The settlement funds demonstrate how particular ecosystem services or functions, in this case water for anadromous fish, influence, guide, and make possible larger projects, including environmental restoration and dam removal. Issues of low to marginal summer flows in the Carmel River were certainly not the only environmental threat facing steelhead (spawning gravel, habitat connectivity, and non-native striped bass are all reported, local concerns), nor were steelhead the only sensitive or threatened species adversely affected by Cal Am's assets on the river. One interview subject, a local recreational angler, pointed out that Pacific lamprey (Entosphenus tridentatus) also faced distinct threats in the river but received comparatively less attention.

The State of California, represented by SCC, contributed the second largest share of funding $(\$ 28,200,000)$ to the removal project. During interviews, one subject who worked closely with the State described a process of "enticement," wherein a demonstration of funds available to cover the cost of removal was used to keep Cal Am interested in the project. Cal Am apparently showed tentative support for the removal and reroute until 2009 when the State entered a financial crisis and most of the State's funds 
were temporarily frozen. At this time, Cal Am reportedly withdrew from negotiations, effectively halting progress on the removal and reroute.

Cal Am eventually rejoined negotiations, a juncture which several interview subjects indicated was a significant moment in the lead-up to removal. Furthermore, all interviewees who had been involved with planning and orchestrating the removal drew attention to the important role of Cal Am president Rob McLean, who took on that position in 2009, following Cal Am's withdrawal from negotiations under the previous company president. As incoming president, McClean reportedly had little knowledge of the issues surrounding the San Clemente Dam and, according to interview subjects, was summoned to the office of local US Congressional Representative Sam Farr. One interview subject, a key member of the project team and government employee, described that period and Farr's intervention.

But Cal Am got a new president and honestly that made the biggest difference. He came and in one of his first months in office. He went to DC and met with Congressman Sam Farr and Sam Farr, who has always loved this project, just read him the riot act; 'why did you guys pull out and backing this project?'

During that conversation, Congressman Farr reportedly informed McClean of the importance of the dam removal and pressured Cal Am to rejoin negotiations.

Subsequently, Cal Am, along with 11 other stakeholders signed a memorandum of agreement, indicating support for the project (California American Water 2010).

The micro-politics behind the removal team and project itself facilitated the actual funding and completion of the San Clemente Dam Removal. As indicated in Table 3, Cal Am contributed $\$ 49,000,000$ to the removal and reroute, an amount equivalent to and determined by the estimated cost of buttressing the dam and keeping it in place, which 
was the least-cost alternative for addressing risks associated with the aging structure. The least-cost alternative was both advantageous to Cal Am (as a for-profit corporation) and also a mandate, given state regulations pertaining to investor-owned utilities.

The majority of water utilities in the United States are publicly owned and managed (Food and Water Watch 2016). In contrast, municipal water on the Monterey Peninsula is supplied by Cal Am (privately owned). This arrangement is part of the historical legacy of infrastructural development and investment on the Monterey Peninsula in the early twentieth century by private enterprises, as well as agreements involving water provision and infrastructure (March 2012). Since Cal Am purchased assets on the Monterey Peninsula in 1966, the local historic records show several instances of dissatisfaction regarding the private utility on the part of locals (March 2012). Most recently, this was exemplified by a successful ballot measure and the Public Water Now campaign, which authorized and directed the Monterey Peninsula Water Management to study a public buyout of the peninsula's water system, implying that steps might be taken towards de-privatization. One interview subject, a lifelong resident of the peninsula and political activist, connected frustrations concerning Cal Am's legacy to a perceived exploitation of ratepayers by $\mathrm{Cal} \mathrm{Am}$, with regard to their contributions towards the removal. The subject felt that Cal Am's shareholders, and not ratepayers, should have born the cost of removal.

California investor-owned utilities are regulated by the California Public Utilities Commission (CPUC), with decisions regarding cost recovery subject to oversight by the Division of Ratepayer Advocates (DRA). These regulatory structures allow the utility (Cal Am) to recover costs associated with the company's "used and useful" assets, in this 
case the dam, through rate increases. However, the utility is required by the DRA to purse the "least-cost alternative." Interview subjects who worked with the removal project team uniformly reported that receiving approval for the removal from the DRA was a significant hurdle because the DRA was pushing Cal Am to pursue buttressing, the "least-cost alternative", over removal. Eventually, with robust cooperation between NMFS, Cal Am, and the SCC, the DRA issued approval for Cal Am to use a rate increase to recoup the costs equivalent to buttressing (California Public Utilities Commission 2012). One interview subject, a senior government official who worked on the removal project in a critical capacity, summarized the relationship between Cal Am, the DRA, and costs associated with the project:

Everybody pretty much agreed, with the exception of Cal Am, that the San Clemente Dam should come out, and the reason Cal Am wanted to stay in was because they said they maintained that it was the cheapest alternative and that the CPUC, the California Public Utilities Commission, says you need to go with a cheapest alternative. So that was their mantra. But when they understood that the difference in costs would be paid for by others, they were much more willing to go along with 'OK, Let's look at other alternatives to buttressing'.

This significant hurdle further demonstrates the obduracy of the structure. Historic legacies around utilities and infrastructural development on the peninsula helped engender a complex system, within which state agencies, in this case the SCC and DRA, worked to enact counterposed agendas. Resolving and overcoming these entanglements was necessary before the material work of dam removal could proceed. Even this relatively bureaucratic process was imbued with political currents and ramifications, especially in the arrangement of a public-private partnership, wherein taxpayers funded the ecologically preferred alternative to dam buttressing and the utility was allowed to divert costs associated with the asset to ratepayers. 
A final point of contention, although one which received little fanfare, came in the form of Cal Am's cost recovery of an additional $\$ 26,000,000$ that they spent studying and working towards dam buttressing (California Public Utilities Commission 2012). With some resistance, the DRA approved rate increases to cover these costs, despite the fact that the spending did not contribute to the finalized form of the project (California Public Utilities Commission 2012). At least one advocacy group (the Public Water Now campaign) voiced frustration with these rate increases, calling them another benefit accrued by the utility at its ratepayer's expense.

The configuration of funding related to the San Clemente Dam Removal comprise an explicitly political outcome. Although they serve a broad constituency, privately owned structures like the San Clemente Dam also generate profits for shareholders and corporations. Yet without a clear plan for their end-of-service-life, the costs, at least in this instance, fall to the public. The state and federal government, in conjunction with local ratepayers, effectively financed the bulk of the San Clemente Dam Removal project. This points to the role politics play in shaping the enviro-technical system and, as a result, overcoming the obduracy of the San Clemente Dam. Despite the fact that the dam itself was reported to have been built with a predicted working lifespan of only 30 years (March 2012), and that Cal Am purchased the structure in full knowledge of its declining utility, it fell to the public to fund the removal. Furthermore, the mechanism by which that funding was acquired, the public-private partnership, is a financial program with its own particular history and politics (see Linder 1999).

Regarding the allocation of costs and benefits pertaining to dam removal, a biologist employed by one of the private firms involved in the project articulated a 
slightly more generous view of the costs of removals.

[A] dam operator, if they've got this huge sort of public liability and then here's an environmental... here's an environmental public concern that can write checks to take it out. Of course, yeah it's a win-win situation for them. 'Here we get to look like really good guys'. And you know on the environmental sides it's a good deal because, hey, we're getting... we're getting environmental benefit. There's no doubt there's environmental benefit.

In the San Clemente case, however, that environmental benefit also served social needs.

Throughout the planning phases of the project, significant attention was given not only to environmental impacts, but to the ways in which the changes to the river's sediment regime resulting from the removal and reroute might affect downstream properties and homeowners. In the following section, I describe and asses the effects of the perceived liabilities having to do with downstream consequences, and how they fundamentally shaped the removal process.

\section{Post-Removal Landscape}

Following the completion of the San Clemente Dam Removal in 2015, the Carmel River now flows for half a mile through the bed of what was formerly San Clemente Creek. This new channel was carefully engineered with attention to gradient, in-stream features, riparian vegetation, and a host of other considerations. The new section of river, the combined flow reach (see Figure 3), is fed by the reroute channel, where the Carmel River was routed through the ridge separating the river from San Clemente Creek. These features, along with the diversion dike blocking the former channel, the sediment stockpile containing the bulk of sediments that had accumulated behind the dam, and the stabilized sediment slope at the downstream end of the sediment stockpile comprise some of the key design elements of the post-removal landscape. 
Herein, I focus on the post-removal landscape in order to examine the ways in which it was shaped by social, political, and ecological values. Revisiting Davis and Slobodkin (2004), I argue that the restoration which took place was fundamentally a value-laden process, one which reveals further understanding as to the broader envirotechnical system pertaining to the San Clemente Dam Removal. Further, I demonstrate the political, social, and ecological efficacy of the post-removal landscape and analyze the landscape as one component in the enviro-technical system of the Carmel River and Monterey Peninsula.

Towards this end, I apply the conceptual lens of techno-politics. Giving specific attention to the political work and agency of artifacts of technology, techno-politics describes and illuminates the values (political and social) projected into the future by durable technological artifacts. Geographers have historically prioritized examination and explication of the shaping of place and landscape, as well as the work landscapes do. There is a strong parallelism, at least at a conceptual level, between my use of the technopolitical frame and a general utilization of landscape. Nevertheless, it is instructive, or at least illuminating, to stick with the analytic metaphor of post-removal landscape as an artifact of technology. I return to Allenby and Sarewitz's definition of technology as a "cause and effect machine" $(2011,36)$, emphasizing the intentionality of the artifact, and the translation of knowledge and technical expertise into material form. Technology, as opposed to landscape, implies origins rooted in invention, rather than emergence.

In examining the post-removal landscape of the San Clemente Dam as an artifact of technology, as well as the values the post-removal landscape projects, I offer a necessarily partial perspective- - highlighting particular characteristics and phenomena 
which became apparent in the research process. I describe environmental values and two distinct more-than-human actors (sediment and fish), using both to demonstrate how political and social values shaped the removal project and resulting landscape. Having then briefly described the values and actors, I subsequently assess the related dominant discourse, identified during the research process through interviews and document analysis. This discourse, which focused on liability, draws particular attention to the role of sediment in the enviro-technical system. The role that sediment plays demonstrates the potential work that the artifact (landscape) can do, in this case maintaining the status quo for downstream property owners.

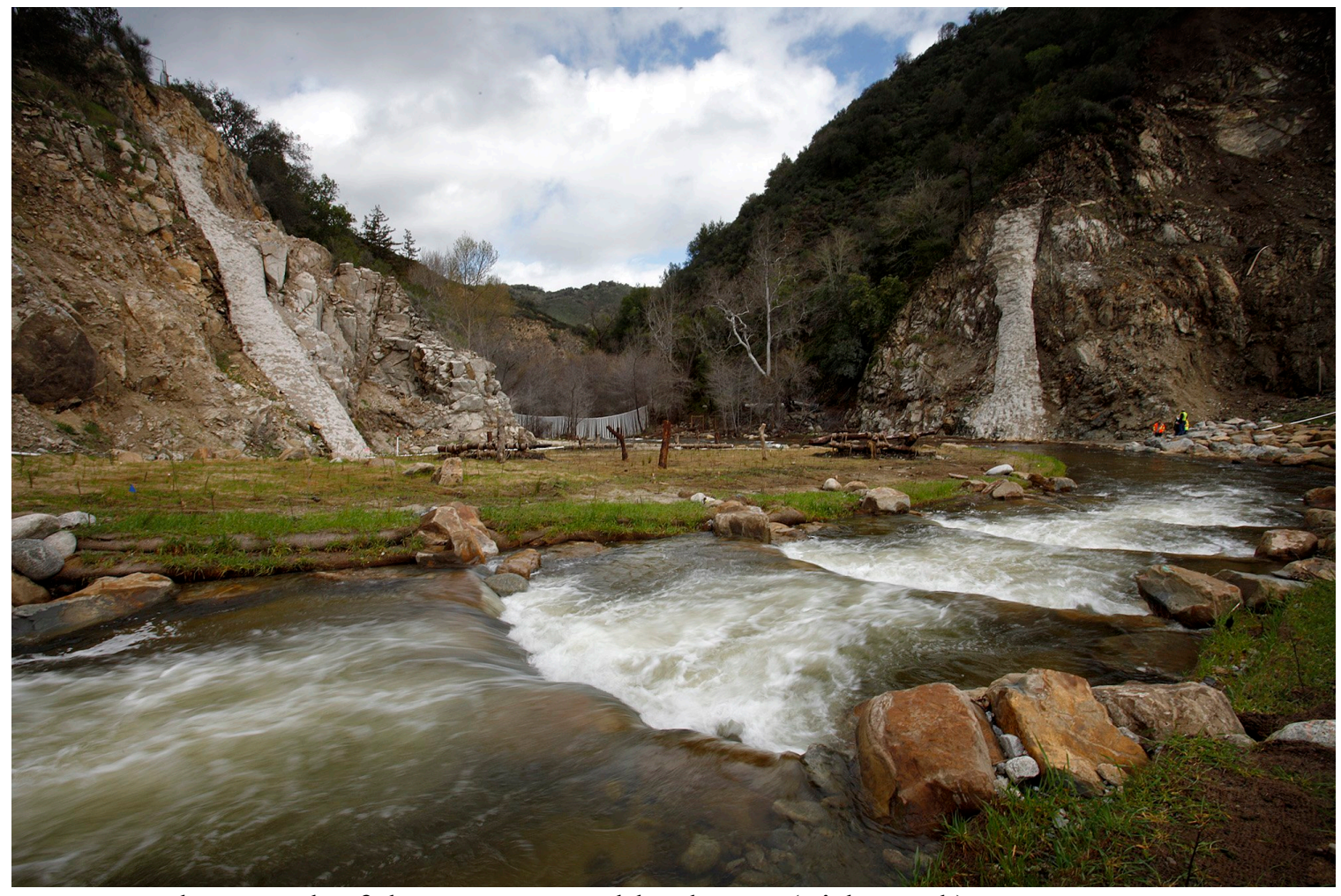

Figure 5. Photograph of the post-removal landscape (Fisher n.d.). 
Steelhead (Oncorhynchus mykiss irideus), are an anadromous form of rainbow trout that were once prevalent from Southern California to Alaska. Currently, many steelhead runs are threatened or endangered. In many areas, including the Carmel River, wild populations of steelhead are supplemented or supported through measures such as captive breeding, and trapping and storage of fish. The aforementioned Central-Southern California Steelhead Evolutionarily Significant Unit, listed as threatened (under the Endangered Species Act) in 1997, became a key protagonist in regional struggles over water, the Carmel River, and dam removal.

Even before negotiations began to remove the San Clemente Dam, the issues affecting steelhead trout had motivated or enrolled various groups of stakeholders into watershed-level actions and struggles. Recreational anglers, represented by the Carmel River Steelhead Association (CRSA) had long sparred with California American Water (see California State Water Resources Control Board 2009). The National Marine Fisheries Service (NMFS) also had institutional and vested interest in steelhead (as directed by the mandate to conserve, manage, and oversee decisions affecting marine species, steelhead included) and played a critical role in driving and shaping dam removal on the Carmel River. This role was demonstrated by their presence on the San Clemente Dam Removal and Reroute project team and as the agency responsible for representing the federal government with respect to this project. During the course of the removal, steelhead's status as a threatened species provided legal power to the NMFS, who were able to threaten the dam owner (Cal Am) with a jeopardy decision as they sought a Section 404 permit through the US Army Corps of Engineers (as directed by the Clean Water Act, referenced earlier). 
Between 1921 and 2015, the San Clemente dam presented significant impediments for steelhead attempting to spawn upstream of the structure. Although fish ladders were installed on the dam, consensus was that the ladder, which was perhaps the steepest of its kind in the state, was a significant obstacle and prevented much of the population from spawning in the upper reaches of the river. Consequently, steelhead and the attendant issues of habitat connectivity were a decided motivating factor in pursuing dam removal over buttressing and the species became a source of leverage for removal advocates.

Concerns over steelhead habitat connectivity promoted changes to the specifics of the reroute design. One interview subject related a dramatic story, where an individual with intimate knowledge of the river and dam site entered (by surreptitious means) a closed-door meeting in order to suggest a design alternative- namely, moving the cut in the ridge between the San Clemente Creek and Carmel River farther upstream, whereby effecting a longer channel within which to reroute the river. The habitat-benefit of this longer channel, which was implemented in the final form of the design and project, was a channel gradient more hospitable to steelhead passage. The newly constructed channel bypassed the bulk of the sediment accumulated behind the San Clemente Dam and was designed with steelhead passage in mind. 54 step pools were carefully engineered using boulders in order to create a gradual passage, with deep pools backed up behind rock ledges for the steelhead to rest in.

All of this focus on steelhead reflects the power of a single species and, more particularly, a single ecosystem service - the river providing habitat connectivity to facilitate spawning. Yet despite the steelhead's importance ecologically, socially, and 
locally, the project focused only on one key ecological benefit for steelhead, namely, habitat connectivity. According to interview subjects, the removal missed the opportunity to replace sediments, particularly spawning gravels, which would have further benefitted steelhead recovery in the Carmel River. One subject, a fisheries biologist involved with the project, described his disappointment after advocating for this additional ecological consideration:

I encouraged the technical group and the project sponsors to, at a minimum, excavate and get some of those spawning materials that had been trapped in the reservoir and have them passed downstream. But, they said this isn't a spawning gravel project, this is a dam removal project. So, I was a little disappointed because a hundred years of spawning gravel retention had occurred and as a result we missed a great opportunity to try to get some of those materials back out, put down them downstream. Sediment retention has caused a lot of problems downstream. We've got channel incision in the lower 15, 16 miles of river in the alluvial portion. And it's due to sediment retention, sediment starvation.

The decision to focus on habitat connectivity and dam removal over spawning gravel and sediments was likely influenced by cost, logistics, and factors beyond the present scope of analysis, but it serves to illustrate the prioritizing of certain environmental considerations over others, indicating the social and micro-political shaping of the project.

Beyond spawning gravels, sediment presented challenges, benefits, and political potentialities that directly shaped other areas and aspects of the San Clemente project. In strictly ecological terms, sediment was most immediately a concern for steelhead with regard to spawning gravel, but simultaneously, the architects of removal voiced concerns over the possibility of adverse consequences for steelhead if sediment accumulated behind the dam was not carefully controlled. While some large dam removals (the Condit and Elwah dams in Washington State, for instance), took place in such a way that 
accumulated sediment was simply allowed to wash downstream, the determination was made that doing so on the Carmel would have significant and pervasive negative effects on both the steelhead and California Red-legged Frog (California Department of Water Resources 2012). The reroute option enacted as part of this project helped to mitigate those risks.

While the spawning gravels which had accumulated behind the dam might remain a missed opportunity, the removal of the dam will likely have the result of allowing sediments and spawning gravel to move downstream, at least unimpeded by the San Clemente Dam (the Los Padres Dam remains in place, upstream of the San Clemente site). The increased sediment load in the river stands to benefit both steelhead and downstream property owners. Multiple interview subjects speculated that increased sediment load in the river would result in an anticipated reduction in bank incision, whereby minimizing property lost each year to the river.

Predicted sediment impacts on property owners presented particular liabilities and potential benefits to the human and economic elements of the enviro-technical system post-removal. While returning the sediment regime to something closer to the river's reference condition might benefit property owners, there was significant attention paid, amongst the design team and removal stakeholders, to the hypothetical impacts of the accumulated sediment behind the dam moving downstream and affecting the lower Carmel River. Specifically, several interview subjects indicated concerns about sediment moving downstream causing flooding and property damage. Whether and how (specifically) sediments affect or might have impacted these properties and property owners is beyond the purview of this study - although there are good indications that 
interview subjects' suppositions are accurate. Nevertheless, concerns over sediments and liability obviously had a demonstrable effect upon the system and removal process.

Throughout my interviews, subjects discussed sediment and the risks associated with the sediment stockpile. Adjacent to these concerns, I identified a common "discourse of liability," exemplified in concern over what might happen in one of several scenarios. These hypothetical scenarios included dam removal without sequestering sediment and the failure of the diversion dike and reroute channel, resulting in the sediment stockpile being washed downstream. Subjects voiced that downstream property owners did not actually indicate any real opposition to the project, but that the presence of homes and valuable real estate in the affected area prompted particular concern. These concerns (as related below by two government officials who worked on the project team) manifest both in terms of downstream property owners benefiting from re-established sediment loads:

Anyone who owns riparian property in the lower valley is a beneficiary because the river is going to carry a heavier sediment load which is going to reduce erosion of their property

....and also interest in the types of homes which would potentially be impacted:

We had million-dollar homes at the bottom of the river that we couldn't just allow all of this to go down and flood out of these homes. 


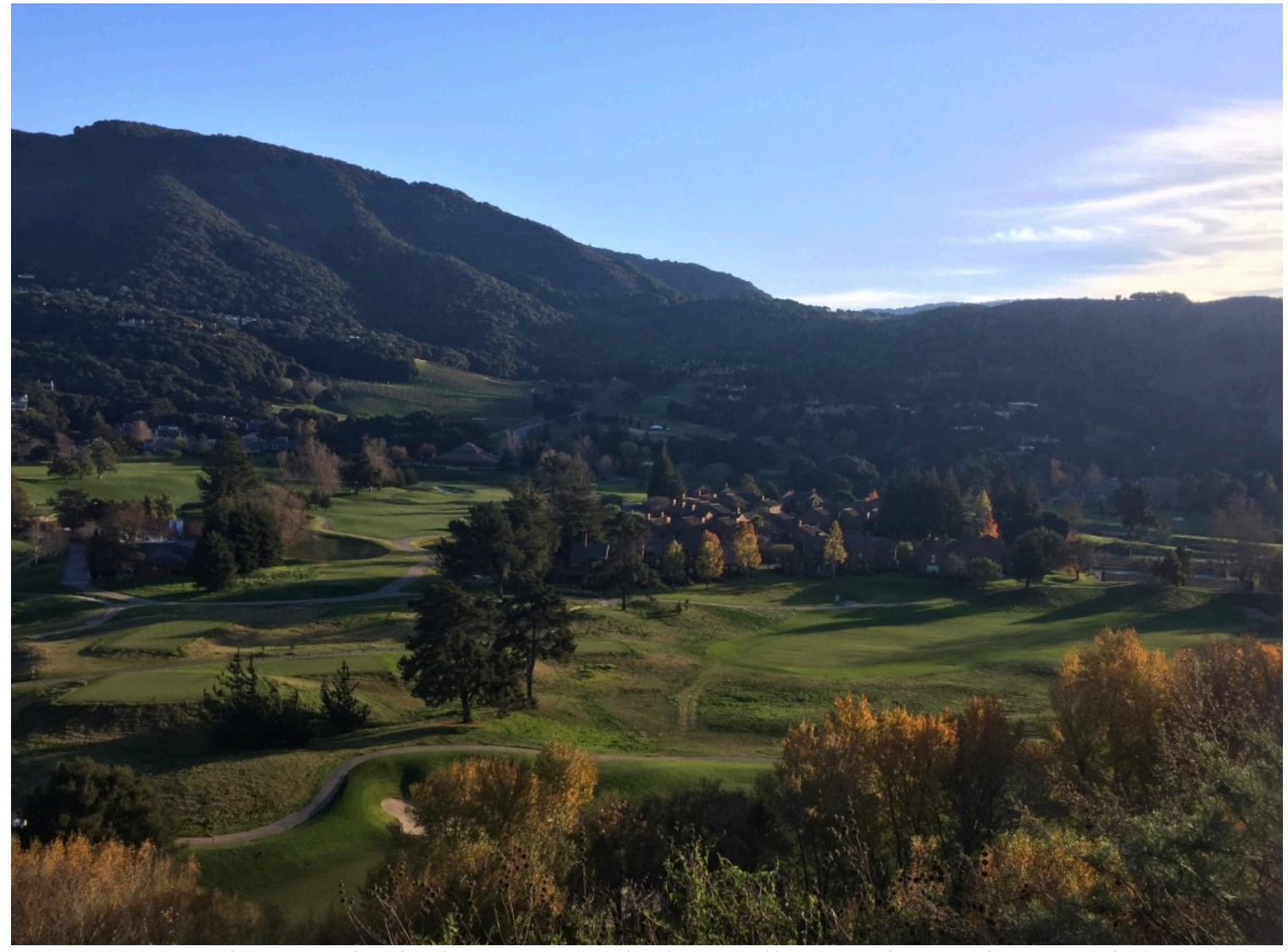

Figure 6. Development in the lower Carmel River valley. Author's photograph.

Concerns over liability and sediment also appear to have influenced a key project component involving ownership of the former dam site. As multiple subjects explained, it was hard to find any agency or group willing to take ownership of the land after the dam was removed. Individuals involved with project planning described familiar concerns over liability relating to the former dam site (in the event of dike failure, etc). Several subjects also related an anecdote wherein Congressman Sam Farr again intervened with respect to this issue, in order to push the project forward. The project team having struggled to find an agency willing to take ownership of the land, and Cal Am reluctant to retain ownership, Sam Farr reportedly exerted pressure on officials in the Bureau of Land 
Management (BLM), who eventually capitulated and agreed that the federal agency would accept the site's 928 acres from Cal Am. Assessing this configuration, one project team representative explained in an interview that this transfer was justified on the basis that the kind of event that would mobilize the sequestered sediment was of such a significant magnitude, given the design standards of the removal and reroute, that any such event would necessarily involve the federal government. Therefore, the likelihood of such a catastrophic event did not significantly increase overall liability for a federal agency like the BLM.

Under this arrangement, wherein the risk of the privately owned dam collapsing has been eliminated, and any risk associated with failure of the reroute and post-removal landscape transferred to the BLM, Cal Am certainly accrues obvious benefits and, in theory, is subject to significantly less liability (discursive or otherwise). Downstream development, historically tied to the San Clemente Dam, was also privileged and benefited from credence given to potential property damage, represented in liability discourse. Finally, the post-removal landscape (as shaped by the above processes) continues to support the local political order by allowing for the profit of an investorowned utility and development patterns of costly real estate along the lower river. The final artifact of technology, the post-removal landscape, therefore has larger political implications, but also is subject to and caught up in micro-politics, or the strategies by which different actors (such as the congressman, the steelhead association, NMFS, and other agencies) exerted influence and power.

The discursive work of liability in this instance also points to the obduracy of the San Clemente Dam. Downriver consequences (hypothetical or otherwise) stalled progress 
on the removal. In other words, the connections within the enviro-technical systembetween river, sediment, dam, and development — reduced the ability to alter the physical structure of the dam. One interview subject, a government employee who worked on the project team, related that $\mathrm{Cal}$ Am had attempted to simply transfer the dam and surrounding land to the public agencies involved, contribute funding for removal, but cease all other involvements with the structure and project; "to which we were like 'nobody in the world is gonna take your damn that has been declared unsafe."'

In the end, the post-removal landscape is a technology that actualizes several goals. It manages sediment, minimizes liability, reconnects habitats, and facilitates continued profit generation for the utility. Both technological and ecological, the landscape was not returned to its reference (or "natural") condition, but was transformed to something that shows evidence of social, political, and environmental values. 


\section{Conclusion, Discussion, and Future Directions}

Dams are, it would seem, an unusual sort of object, as difficult or more to remove as they are to construct. When the San Clemente Dam was built, it became a part of the enviro-technical system encompassing the Carmel River and water provision on the Monterey Peninsula. Over the next century, the dam accrued entanglements and connections within the system, adding to the structure's obduracy.

The San Clemente Dam Removal involved a myriad of actors, stakeholders, and subplots, many of which remain for future analysis. An effective, politically attentive understanding of dam removal requires attention to both the complex array of human, governmental, and social actors, as well as the technical, physical, non-human dimensions involved. Given the sheer volume of actors enrolled within the context of a single removal project, the data available to researchers may quickly become overwhelming. As a senior federal government official, intimately involved with the removal of the San Clemente Dam, relayed in the course of this study, "You're not going to find one person who knows the full scope of what happened."

This overabundance of relevant information demands the focusing potential of an analytical framework. In this study, I have presented a few key concepts as clarifying tools, directing academic attention toward the physical artifacts involved in the removal project. I argue that it is not enough to acknowledge that the dam and the post-removal landscape were "shaped" by political forces, or that they had some "effects" on people and the biophysical river. In order to effectively investigate these elements, they must be considered as artifacts imbued with politics and enrolled in enviro-technical systems. 
The porous enviro-technical system into which the dam was built changed and developed around the dam, adding connections and linkages between the structure and human and more-than-human actors. Continued development in the area taxed the available drinking water, as new properties and golf courses were built along the lower river. Meanwhile, sediments accumulated behind the dam as fire and other disturbance events affected the surrounding forest. Simultaneously, systems of governance (which had formerly either not existed or not yet reached the dam) came to encompass the structure - the California Department of Water Resources, The California Public Utilities Commission, The US Army Corps of Engineers, and the National Marine Fisheries service all grew in jurisdiction, to eventually include the dam.

Politics, the struggle for recognition or the ability to exert outsized influence, is implicated throughout the dam's timeline and historical developments, manifesting in a variety of scales, means, and venues. At a fundamental level, the dam itself was built with inherent politics. Perhaps most relevantly, it projected certain environmental issues (and thereby values) into the future and, for most of its service life, without a plan to address the material consequences of the aging structure. Impacts to steelhead remain among the most visible effects of the dam, and the political implications of those effects are illustrated through other stakeholder groups' responses to dwindling fish stocks. The Carmel River Steelhead Association was established as a direct response to degradation of the river and dwindling numbers of fish, and the subsequent conflicts and legal clashes between the Association and California American Water demonstrate struggles for influence over the river. 
Impacts to steelhead, characterized by low flows in the river, retention of spawning gravels behind the dam, and impeded fish passage at the San Clemente Dam, also enrolled or compelled the engagement of the National Marine Fisheries Service in the river's governance. In the history of the dam, we see politically significant contests and maneuvers between the NMFS and Cal Am, particularly in the decade prior to 2010. Some of the environmental impacts related to steelhead, and their associated political struggles, are somewhat ancillary to the issue of dam removal. For instance, low flows in the river and water scarcity on the Monterey Peninsula in the years following 2003 (when the dam last provided any drinking water), had only indirect impacts on the removal process. Nevertheless, those issues (and the political contests they helped engender) were all within the same enviro-technical system, encompassing the dam, river, and water provision to the Monterey Peninsula.

The San Clemente Dam's inherent politics also manifest through its historical connection to development in the region. The dam was part of the material, infrastructural network of private water provision, an organization which itself implies a political order and sets the region apart from most of the State of California and the broader American West. This arrangement was closely linked to the development of tourism and real estate throughout the twentieth century.

Beyond the inherent politics of the dam, the process by which the technological practice of removal came to the Carmel River demonstrates noteworthy political implications and shaping. The work of translating removal technology to the local context features adjustments to meet or balance political perspectives. The difficult negotiations which preceded removal highlight the work of different stakeholder groups 
and episodes. For instance, the importance that NMFS put on steelhead habitat connectivity (enforced through their Section 7 mandate), highlights how the particular political landscape of the dam, river, and enviro-technical system shaped the removal process.

Despite the multitude of motivations and supporters for removal, the dam was a decidedly obdurate artifact. The dam's material qualities, its mass and size, made its removal an engineering challenge. The structure was also networked within a complex, porous system. As Hommels (2015) points out (albeit in a different scholarly context), this networking and the linkages between system elements are a key explanatory framework for obduracy. The network, in this case, is understood as the enviro-technical system. Following Pritchard's (2011) model, the enviro-technical system of the San Clemente Dam is composed of technological (water infrastructure in the region), environmental (the Carmel River ecosystem), social (residents and developments), and political (the array of interest groups) elements. Understanding the composition and basic functions of this enviro-technical system helps to demonstrate why the removal process took decades to overcome the dam's basic obduracy.

That effort, or the process of overcoming the dam's obduracy also shows distinct episodes where politics came into play and shaped the project—most visibly with respect to micro-political strategies between different stakeholders and interest groups. Tactics such as the preferencing of different engineering plans, and negotiations over funding fall under this rubric. The influence of politics on the project is also apparent through consideration of the removal's beneficiaries and the political order that it helps to support. As I explored through the mechanisms of funding, the San Clemente Removal 
perpetuated a sometimes-contested arrangement whereby an investor-owned utility benefited through a public-private partnership, largely funded through rate increases on its constituents.

Although the original research design for this study included discourse analysis as a critical component, no strong link was established between discourse and politics in the course of study. Nevertheless, I did identify one relevant discourse (around risk and liability), that significantly shaped the project. While the political significance of liability discourses was not as prominent as other topics of analysis, it nevertheless made some impact on the design of the reroute and removal, represented in the post-removal landscape. As an artifact of technology, the post-removal landscape shows the influence of social and political values as well as a propensity to function in support of those same values. Concern for downstream properties weighed heavily on the design, as did particular environmental services, namely habitat connectivity for steelhead.

While this artifact (and the technology of dam removal) sometimes made it into the public consciousness or popular press, most of the political processes I have outlined took place out of the view of the public. The public was involved at various stages, and several agencies took real steps towards raising public awareness or soliciting feedback, but the negotiations, strategies, and machinations which form the bulk of my analysis were primarily conducted between a relatively small number of agents. Future research would, therefore, do well to examine these negotiations, or similar projects, through the academic lens of post-politics (see Anderson et al. 2016, Swyngedouw and Wilson 2014). Furthermore, the future analyses of similar projects could also include ongoing work on the removal site as well as a more thorough examination of local water issues. 
Having established some of the means by which politics figure into dam removal, future work on this, or similar case studies would also benefit by asking more detailed research questions. It would be particularly interesting to consider a more detailed analysis of who benefits from dam removal, how they benefit, and through what processes, following the recent prompting of Grabowski et al. (2017). Further, I suggest that the question of "who benefits" via dam removal also implies the question of "who loses"”, or from whom benefits are accrued. Loftus et al. (2016) have demonstrated the role of water infrastructure (in their case household water meters) in creating financial subjectivities. Although contextually removed, a more detailed study of the San Clemente case, focusing on the role of investor-owned utility Cal Am, or dam removal and dam owners more generally, might yield significant insights into the power relationship between dam owners and ratepayers.

Research into these topics could potentially benefit from the sort of discourse analysis I originally proposed for this study. One drawback to the research design for this project seems to have been in looking for discourse around events that had already occurred, mostly out of the view of the public. What discourse I found was not quite so active, nor did it appear to be actively supporting current regimes of truth or project components. Instead, my research revealed a rich history of obduracy and envirotechnical systems, which I have chosen to include in this case study.

Finally, future research might also consider in more depth questions about the end of service life for artifacts such as dams. As I have worked to demonstrate in this study, the political implications and efficacy of the San Clemente Dam did not neatly end as the dam ceased to function. Rather, the process of addressing the aging structure, mitigating 
the hazards it posed, and altering its ecological impacts was wrought with politics. In particular, the politics of removal funding, which in the case of the San Clemente Dam were of demonstrated political significance, may provide an avenue for understanding the full spectrum of politics as manifest in dams. More broadly, social science and geographic research might consider the undoing of infrastructure along the same lines.

What does it then say about the nature of technology and infrastructure that the cost of dam can be passed from dam owners to the public? The San Clemente Dam was a privately owned asset, and yet the removal project was funded by ratepayers and taxpayers. Rarely, it seems, do we consider the end-of-life for artifacts of technology as they are produced. The politics of funding may prove a compelling means to address broader questions of de-growth, de-industrialization (or re-industrialization) and similar processes where society confronts obduracy, obsolescence, or the politics projected though time by aging infrastructure.

This study has examined the role and work of politics in dam removal. By considering the enviro-technical system within which the San Clemente dam was built, the structure's inherent politics and obduracy, as well as the work of politics through and after the removal process, I have attempted to present a comprehensive view of the politics of dam removal. This historically attentive perspective on removal made visible several instances of politics and political shaping. Given the significance of the dam and Carmel River to the Monterey Peninsula, the work of politics in this dam removal project has a decided regional relevance. Beyond the San Clemente Dam, we will continue to face questions about the fate of aging dams and other works of infrastructure. 
Understanding the work of power and politics will, I believe, remain an important task as we answer these questions. 


\section{References}

Allenby, B. R., \& Sarewitz, D. (2011). The techno-human condition. Cambridge, MA: MIT Press.

Anderson, M. B., Ward, L., McEvoy, J., Gilbertz, S. J., \& Hall, D. M. (2016).

Developing the water commons? The (post) political condition and the politics of "shared giving" in Montana. Geoforum, 74, 147-157.

Bakker, K. (1999). The politics of hydropower: developing the Mekong. Political Geography, 18(2), 209-232.

Bennett, J. (2009). Vibrant matter: A political ecology of things. Durham, NC: Duke University Press.

Berry, K. A. (2014) "Actor-network theory and traditional cultural properties: Exploring irrigation as a hybrid network in $19^{\text {th }}$ century Hawai 'i," Human Geography 7(2): 73-87.

Bichsel, C. (2016). Water and the (infra-) structure of political rule: A synthesis. Water Alternatives, 9(2), 356-372.

Bijker, W. E. (2007). Dikes and dams, thick with politics. Isis, 98(1), 109-123.

Blumm, M. C., \& Erickson, A. B. (2012). Dam removal in the Pacific Northwest: Lessons for the nation. Environmental Law, 1043-1100.

Brooks, K. B. (2009). Public power, private dams: The Hells Canyon high dam controversy. Seattle, WA: University of Washington Press.

California American Water (n.d.). San Clemente dam removal and Carmel River reroute. $\mathrm{http}: / /$ www.sanclementedamremoval.org

California American Water (2009). Final environmental impact report: Coastal water project.

California American Water (2010). San Clemente Dam removal project collaboration statement.

California American Water and National Marine Fisheries Service (2006). Settlement agreement.

California Department of Water Resources (2012). Final supplement to the environmental impact report: San Clemente Dam seismic safety project. 
California Department of Water Resources \& US Army Corps of Engineers (CDWR \& USACE) (2008). Final environmental impact report/environmental impact statement: San Clemente Dam seismic safety project.

California Public Utilities Commission (2012). Application of California-American Water Company (U210W) for authorization to implement the Carmel River Reroute and San Clemente Dam Removal Project and to recover costs associated with the project in rates (Decision 12-06-040). San Francisco, CA.

California State Coastal Conservancy (n.d.). San Clemente dam removal project description. http://scc.ca.gov/webmaster/ftp/pdf/sccbb/2008/0809/0809Board03A_San_Clemente_Da m_Removal_Ex2.pdf.

California State Water Resources Control Board (2009). Draft cease and desist order against California American Water for unauthorized diversion of water from the Carmel River in Monterey County. Sacramento, CA.

Carroll, P. (2012). Water and technoscientific state formation in California. Social Studies of Science, 42(4), 489-516.

Carse, A. (2012). Nature as infrastructure: Making and managing the Panama Canal watershed. Social Studies of Science, 42(4), 539-516.

Chiang, C. Y. (2009). Shaping the shoreline: Fisheries and tourism on the Monterey coast. Seattle, WA: University of Washington Press.

Clewell, A. F., \& Aronson, J. (2006). Motivations for the restoration of ecosystems. Conservation Biology, 20(2), 420-428.

Cote, M., \& Nightingale, A. J. (2012). Resilience thinking meets social theory: situating social change in socio-ecological systems (SES) research. Progress in Human Geography, 36(4), 475-489.

Cronon, W. (2009). Nature's metropolis: Chicago and the great west. New York, NY: W. W. Norton \& Company.

Crow-Miller, B. (2015). Discourses of deflection: the politics of framing China's southnorth water transfer project. Water Alternatives, $8(2)$.

Crow-Miller, B., Webber, M., \& Molle, F. (2017). The (re)turn to infrastructure for water management?. Water Alternatives.

Davis, M. A., \& Slobodkin, L. B. (2004). The science and values of restoration ecology. Restoration Ecology, 12(1), 1-3. 
Doyle, M. W., Stanley, E. H., \& Harbor, J. M. (2003). Channel adjustments following two dam removals in Wisconsin. Water Resources Research, 39(1).

Doyle, M. W., Stanley, E. H., Orr, C. H., Selle, A. R., Sethi, S. A., \& Harbor, J. M. (2005). Stream ecosystem response to small dam removal: Lessons from the heartland. Geomorphology, 71(1), 227-244.

Evenden, M. D. (2004). Fish versus power: an environmental history of the Fraser river. Cambridge: Cambridge University Press.

Fisher, Vern (n.d.). Untitled photograph of the San Clemente dam site. Retrieved from http://www.waterfindusa.com/news-posts/new-hope-scrutiny-carmel-river-wake-damremoval-rerouted-channel/

Food \& Water Watch (2016). The state of public water in the United States. Washington DC.

Fox, C. A., Magilligan, F. J., \& Sneddon, C. S. (2016). "You kill the dam, you are killing a part of me": Dam removal and the environmental politics of river restoration. Geoforum, 70, 93-104.

Forsyth, T. (2004). Critical political ecology: The politics of environmental science. New York, NY: Routledge.

Gorthy, J. (2018, May 17). For surfing, kayaking or floating through, Bend Whitewater Park is a watersports wonder. The Register Guard. Retrieved from https://www.registerguard.com/

Gosnell, H., \& Kelly, E. C. (2010). Peace on the river? Social-ecological restoration and large dam removal in the Klamath basin, USA. Water Alternatives, 3(2), 362.

Grabowski, Z. J., Denton, A., Rozance, M. A., Matsler, M., \& Kidd, S. (2017). Removing dams, constructing science: Coproduction of undammed riverscapes by politics, finance, environment, society and technology. Water Alternatives, 3(3), 769.

Hart, D. D., Johnson, T. E., Bushaw-Newton, K. L., Horwitz, R. J., Bednarek, A. T., Charles, D. F., \& Velinsky, D. J. (2002). Dam removal: Challenges and opportunities for ecological research and river restoration. BioScience, 52(8), 669-682.

Hatten, J. R., Batt, T. R., Skalicky, J. J., Engle, R., Barton, G. J., Fosness, R. L., \& Warren, J. (2016). Effects of dam removal on Tule fall Chinook salmon spawning habitat in the White Salmon River, Washington. River Research and Applications, 32(7), 14811492. 
Hay, I. (2000). Qualitative research methods in human geography. Oxford: Oxford University Press.

Hobbs, R. J., Higgs, E., \& Harris, J. A. (2009). Novel ecosystems: implications for conservation and restoration. Trends in ecology \& evolution, 24(11), 599-605.

Hecht, G. (2001). Technology, politics, and national identity in France. Technologies of Power: Essays in Honor of Thomas Parke Hughes and Agatha Chipley Hughes, 253-293. Cambridge, MA: MIT Press.

Hecht, S. B. (1985). Environment, development and politics: capital accumulation and the livestock sector in eastern Amazonia. World Development, 13(6), 663-684.

Hommels, A. (2005). Studying obduracy in the city: Toward a productive fusion between technology studies and urban studies. Science, technology \& human values, 30(3), 323351.

Hughes, T. P. (1987). The Evolution of Large Technological Systems. In W. Bijker, T.P. Hughes, \& T. Pinch (Eds.), The Social Construction of Technological Systems: New Directions in the Sociology and History of Technology (pp. 51-82). Cambridge, MA: MIT Press.

Hughes, T. P. (1993). Networks of power: Electrification in western society, 1880-1930. Baltimore, MD: Johns Hopkins University Press.

Hundley, N. (1992). The Great Thirst: Californians and water, 1770s-1990s. Berkeley, CA: University of California Press.

Jordan, W.R. (2010) Some reflections on Curtis Prairie and the genesis of ecological restoration. Ecological Management \& Restoration, 11(2), 99-107.

JRP Historical Consulting (2014). A Legacy in Stone and Concrete: The Old Carmel River and San Clemente Dams.

Kaika, M. (2006). Dams as symbols of modernization: The urbanization of nature between geographical imagination and materiality. Annals of the Association of American Geographers, 96(2), 276-301.

Khagram, S. (2004). Dams and development: Transnational struggles for water and power. Ithica, NY: Cornell University Press.

Lafrenz, M. D., Bean, R. A., \& Uthman, D. (2013). Soil ripening following dam removal. Physical Geography, 34(2), 124-135. 
Latour, B. (2005). Reassembling the social: An introduction to actor-network-theory. Oxford: Oxford University Press.

Latour, B. (1992). Where are the missing masses? The sociology of a few mundane artifacts. In W. Bijker \& J. Law (Eds.), Shaping technology/building society: Studies in sociotechnical change (pp. 225-258). Cambridge, MA: MIT Press.

Lave, R., Doyle, M., \& Robertson, M. (2010). Privatizing stream restoration in the US. Social studies of science, 40(5), 677-703.

Lejon, A. G., Renöfält, B. M., \& Nilsson, C. (2009). Conflicts associated with dam removal in Sweden. Ecology and Society, 14(2).

Linder, S. H. (1999). Coming to terms with the public-private partnership: A grammar of multiple meanings. American Behavioral Scientist, 43(1), 35-51.

Loftus, A., March, H., \& Nash, F. (2016). Water infrastructure and the making of financial subjects in the south east of England. Water Alternatives, 9(2), 319-335.

Lowry, W. R. (2003). Dam politics: Restoring America's rivers. Washington, D.C.: Georgetown University Press.

Magilligan, F. J., Graber, B. E., Nislow, K. H., Chipman, J. W., Sneddon, C. S., \& Fox, C. A. (2016). River restoration by dam removal: Enhancing connectivity at watershed scales. Elementa: Science of the Anthropocene, 4(108).

Magilligan, F. J., Sneddon, C. S., \& Fox, C. A. (2017). The social, historical, and institutional contingencies of dam removal. Environmental Management, 59(6), 982-994.

March, R. A. (2012). River in ruin: The story of the Carmel river. Lincoln, NE: University of Nebraska Press.

McCully, P. (1996). Silenced rivers: The ecology and politics of large dams. London: Zed Books.

Meehan, K. (2013). Disciplining de facto development: Water theft and hydrosocial order in Tijuana. Environment and Planning D: Society and Space, 31(2), 319-336.

Meehan, K. M. (2014). Tool-power: Water infrastructure as wellsprings of state power. Geoforum, 57, 215-224.

Michel, J. T., Helfield, J. M., \& Hooper, D. U. (2011). Seed Rain and Revegetation of Exposed Substrates Following Dam Removal on the Elwha River. Northwest Science, 85(1), 15-29. 
Mitchell, T. (2002). Rule of experts: Egypt, techno-politics, modernity. Berkeley, CA: University of California Press.

Molle, F., Mollinga, P. P., \& Wester, P. (2009). Hydraulic bureaucracies: Flows of water, flows of power. Water Alternatives, 2(3), 328.

Monterey Peninsula Water Management District (1989). Technical memorandum 88-03: Evaluation of Reservoir Sedimentation Rates in the Upper Carmel River Watershed. Monterey, CA: G. Matthews.

Monterey Peninsula Water Management District (n.d). About MPWMD. Retrieved from http://www.mpwmd.net/who-we-are/about-mpwmd/.

MWH Americas (2008). Final basis of design report: Carmel River reroute and San Clemente Dam removal, Monterey County, California. Walnut Creek, CA.

Nietschmann, B. Q. (2001). The Nietschmann syllabus: A vision of the field. Geographical Review, 91(1-2), 175-184.

Pizzuto, J. (2002). Effects of dam removal on river form and process. BioScience, 52(8), 683-691.

Pritchard, S. B. (2004). Reconstructing the Rhône: The cultural politics of nature and nation in contemporary France, 1945-1997. French Historical Studies, 27(4), 765-799.

Pritchard, S. B. (2011). Confluence: the nature of technology and the remaking of the Rhône. Cambridge, MA: Harvard University Press.

Reisner, M. (1993). Cadillac desert: The American West and its disappearing water. New York, NY: Penguin Books.

Shafroth, P. B., Friedman, J. M., Auble, G. T., Scott, M. L., \& Braatne, J. H. (2002). Potential responses of riparian vegetation to dam removal. BioScience, 52(8), 703-712.

Shaw, I. G. R., \& Meehan, K. (2013). Force-full: Power, politics and object-oriented philosophy. Area, 45(2), 216-222.

Sneddon, C. (2015). Concrete revolution: Large dams, Cold War geopolitics, and the US Bureau of Reclamation. Chicago, IL: University of Chicago Press.

Sneddon, C., \& Fox, C. (2011). The Cold War, the US Bureau of Reclamation, and the technopolitics of river basin development, 1950-1970. Political Geography, 30(8), 450460 . 
Stanley, E. H., \& Doyle, M. W. (2003). Trading off: The Ecological Effects of Dam Removal. Frontiers in Ecology and the Environment, 1(1), 15-22.

Steinbeck, J. (1994). Cannery Row. New York, NY: Penguin Books. (Original work published in 1945)

Swyngedouw, E., \& Wilson, J. (2014). The post-political and its discontents. Edinburgh: Edinburgh University Press.

Schnitzler, A. (2013). Traveling technologies: Infrastructure, ethical regimes, and the materiality of politics in South Africa. Cultural Anthropology, 28(4), 670-693.

Walker, P. A. (2007). Political ecology: Where is the politics?. Progress in Human geography, 31(3), 363-369.

White, R. (1996). The organic machine: The remaking of the Columbia River. London: Macmillan.

Winner, L. (1980). Do artifacts have politics?. Daedalus, 109(1), 121-136.

Woodward-Clyde Consultants (1992). Seismic and flood stability evaluation, San Clemente Dam report.

Worster, D. (1985). Rivers of Empire: Water, Aridity, and the Growth of the American West. Oxford: Oxford University Press. 


\section{Appendix: Semi-Structured Interview Questions}

- Would you mind introducing yourself and briefly describe your position and organization?

○ What kind of work does your organization do?

- Please describe your connection to the removal of the San Clemente Dam .

- How did you come to be involved with this project?

- How did your agency, group, or organization come to be involved with this project?

- Can you describe how the project played out or unfolded?

$\circ$ Were there any moments or events you might consider especially significant?

○ Why or why not?

- Are there any details of the project you think are worth highlighting?

○ Why do you feel these details are important?

- How would you describe the public's access to information about the project?

○ How would you describe your information?

- How much influence do you feel you (or your organization/agency) had over the project?

○ Were there any strategies your employed in order to exert more influence?

- Which parties or interest groups do you believe had the most influence over the way the project took place?

- Were there parties you think should have had more influence or less influence?

- Was this influence contentious/controversial in any way?

- How do you feel this influence was won or lost?

- Did you feel there were political dimensions to this removal?

- Can you describe those dimensions?

- How would you characterize the interactions between private interests (dam owner, etc.) and public interests?

- Can you comment on the way the funding of the project was handled?

- Can you comment on the design of the removal and the re-route?

- What do you think led to the reroute option (as opposed to other removal options)?

- What do you think determined the form of the removal?

- Social issues? Environmental Concerns? 
- Who do you believe were the ultimate beneficiaries, now that the project has been completed?

○ Were there specific interests or viewpoints that lost out?

- What were your feelings about the dam (pre-removal)?

$\circ$ What did the dam represent to you?

- What do you believe the dam removal and reroute accomplished?

- At any point, did you (or your group/agency/etc) experience resistance or conflict with others?

- Can you describe the terms of the conflict or the points of contention?

- What do you believe was the strongest motivation/driver for the project?

- Were you supportive of the removal project?

- Why/why not?

○ Were you always supportive of/against removal or did your position change at some point?

- Anything else you want to add: 